\title{
الأبعاد القانونية لجريمة التوسط في اخذ العطية او الفائدة في النظام الجزائي السعودي دراسة تحليلية نقدية
}

\author{
دكتور \\ عبد اللّه ماجد عبد المطلب العكايلة \\ أستاذ القانون الجنائي المساعد - قسم القانون \\ كلية العلوم والدراسات الإنسانية \\ جامعة الأمير سطام بن عبد العزيز \\ الخرج - المملكة العربية السعودية
}





\section{|llill}

يكمن موضوع بحثنا ب ( الأبعاد القانونية لجريمة التوسط في أخذ العطية او الفائدة وفقاً للنظام الجزائي السعودي) تعرضنا لبيان مفهوم هذه الجريمة و اختلافها

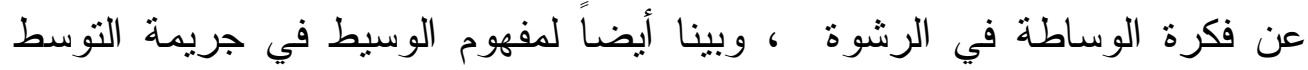

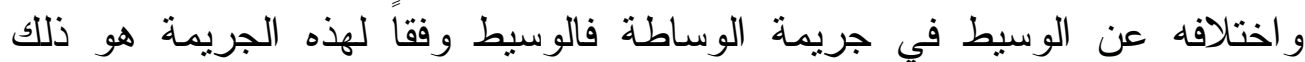
الثخص الذي يتم تكليفه من قبل الر اثتي او المرتشي او كلاهما معا للقيام بأعمال

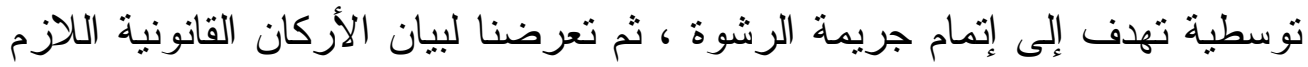

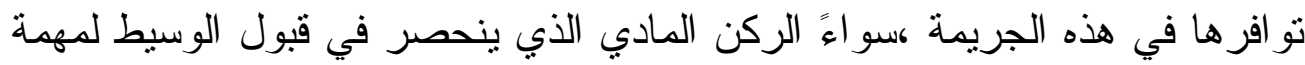

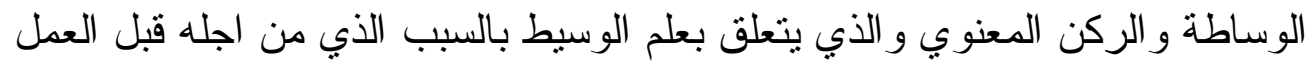

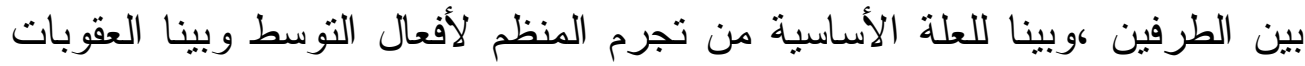

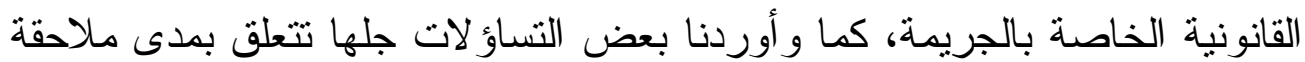

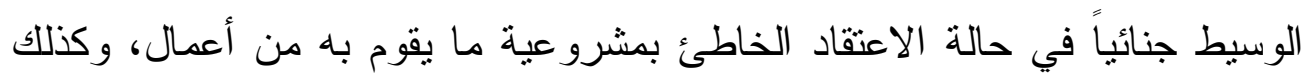

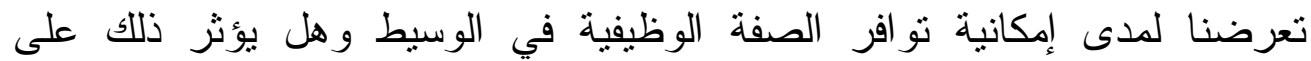
مسؤولية الجنائية، وقد تعرضنا لمدى إمكانية تصور الثروع في الجريمة، و انتهينا

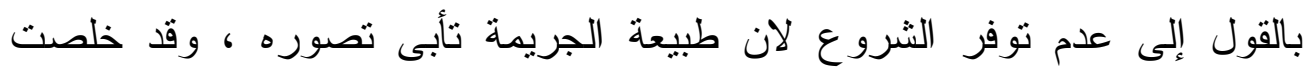

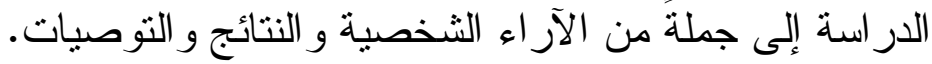




\section{Abstract}

The research focuses on the legal system of the mediating crime by giving gifts or interest in accordance with the Saudi penal system. This research reported this crime and the bribery crime. The mediator according to this crime is the person who is or both of them to carry out ، the bribed assigned by the bribe mediation work aimed at the completion of the crime. We also discussed the legal principles that should be available in this crime. These principles could be connected with materiality or ،criteria by accepting the mediator to accomplish this crime unmaterial criteria by advance knowledge about the mission. The legal principles regarding this crime were explained in addition to the corresponding penalties. Some questions regarding the applicability of penalty on the mediator in case he/she misunderstood the legality of his work were addressed. The position of the mediator and its influence on his/her crime ،was addressed also. The initiation of this crime was discussed and we concluded that this branch is not possible based on the this investigation summarized snature of the crime. Finally several conclusions and recommendations regarding this crim 


\section{مقدمة مقة}

تعتبر جريمة الرشوة وما يلحق بها من أكثر الجرائم خطورةً ، لما يترتب عليها

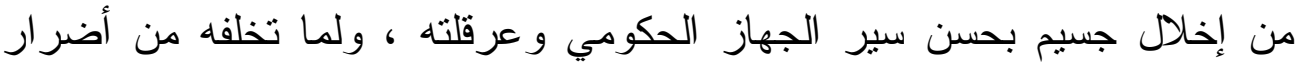

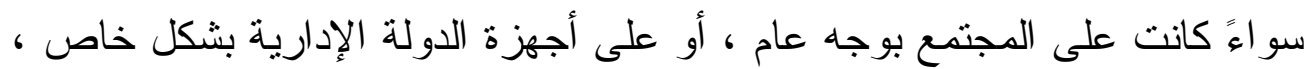

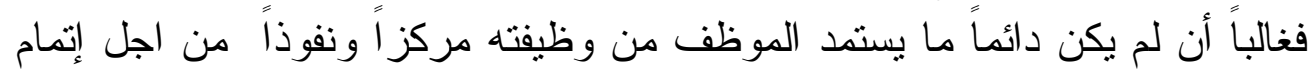

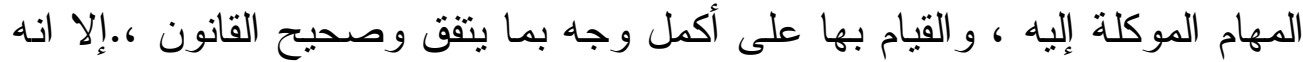

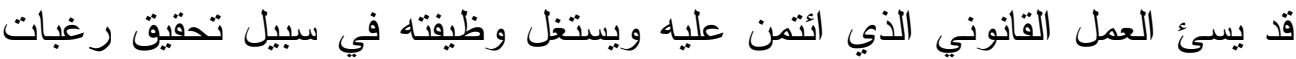

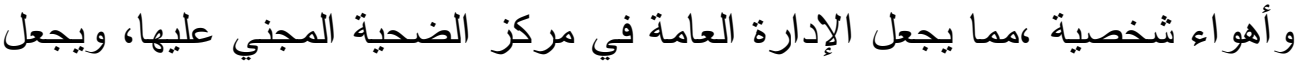

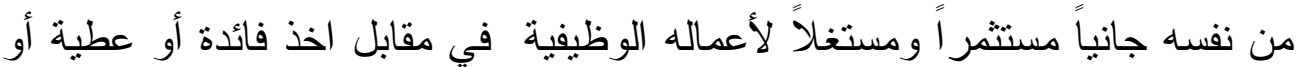

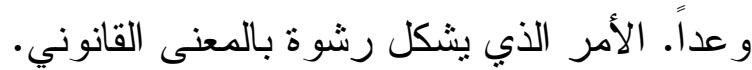

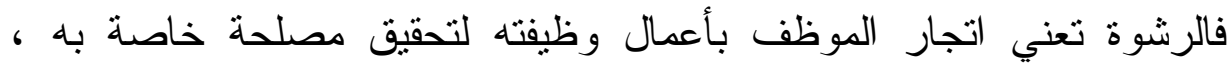
بمعنى انحر اف الموظف في أدائه لأعماله الوظيفية عن الغرض المستهدف من هذا

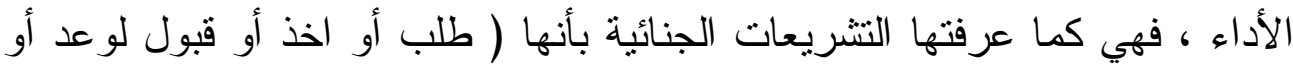

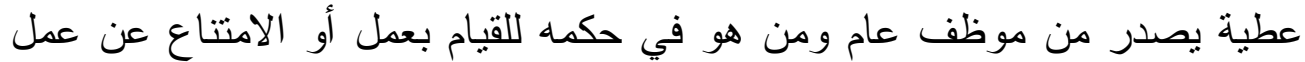

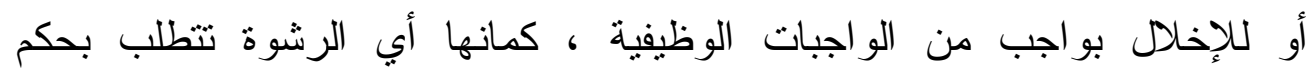

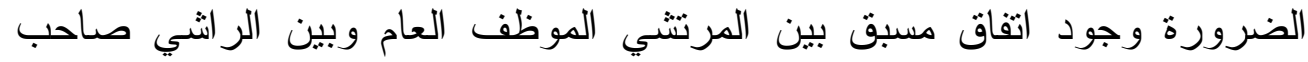
الحاجة ، بحيث يحصل الموظف على الفائدة أو العطية المتفق عليها نتيجة قيامه بأعمال لصالح صاحب الحاجة. ونظر اً لفداحة الأضر ار الناتجة عن جريمة الرشوة وما تخلفه من أضر ار وخيمة

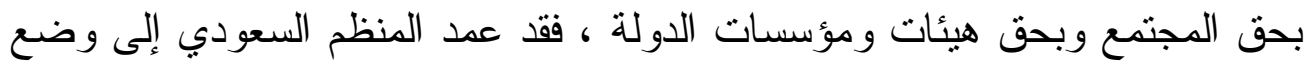
عقوبات صارمة بشأنها ، لا بل و عاقبات ومونى على أفعال أخرى تدخل في نطاقها نتلغ

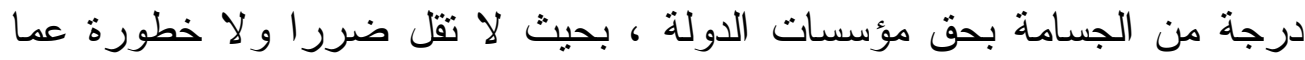
تتتجه جريمة الرشوة ، و أطلق على هذونس هذه الأفعال اسم " الجرائم الملحقة بجريمة

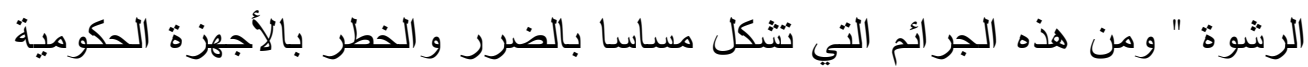

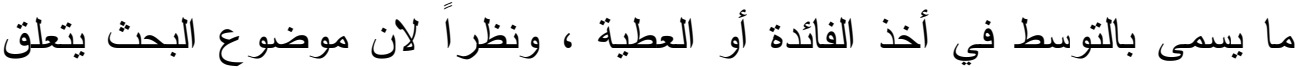

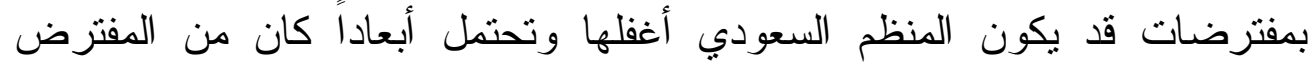

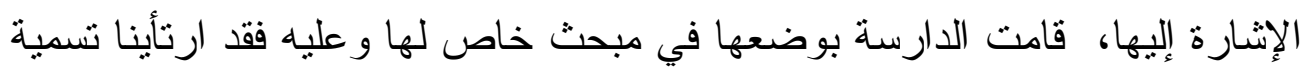
بحثنا ب " الأبعاد القانونية لجريمة التوسط في اخذ العطية أو الفائدة وفقاً للنظام الجزائي الخاص السعودي" ، ولعل جريمة التوسط في أخذ الفائدة تتطلب وجود 
شخص ثالث بين الر اثي و المرتشي يمارس أعماله بناءً على تكليف أو تعيين من

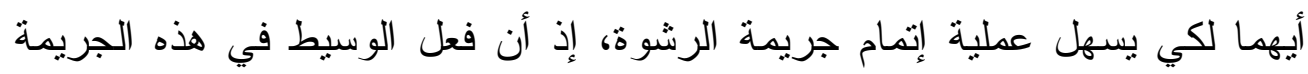

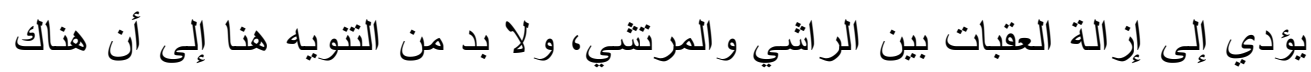
اختلاف على نحو ما سنرى بين هذه الجريمة وجريمة الوساطة في الرشوة.

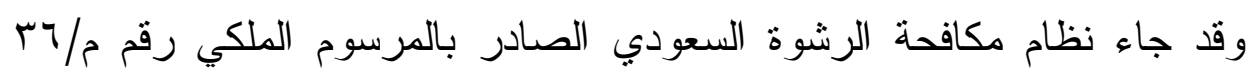

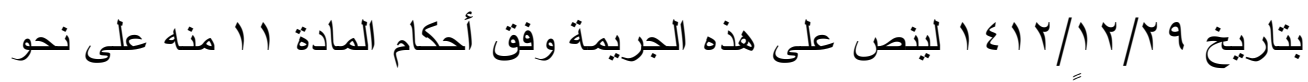
ما سنرى لاحقاً.

\section{سبب اختيار البحث}

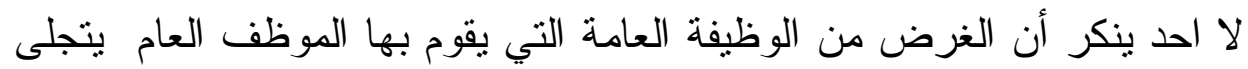

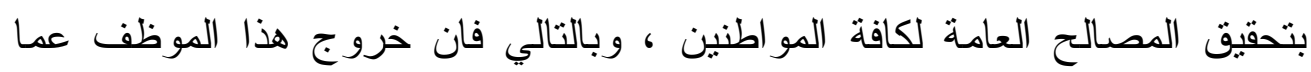

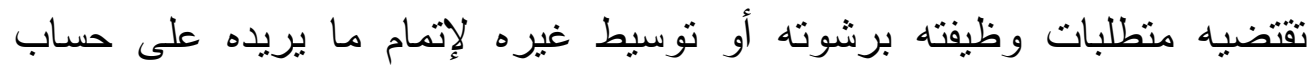

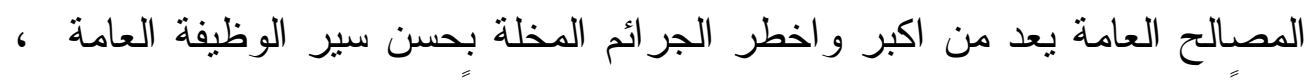

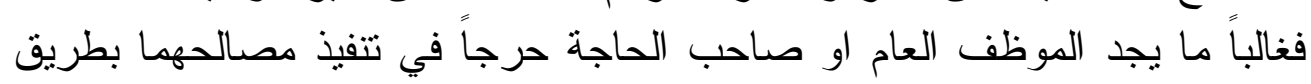

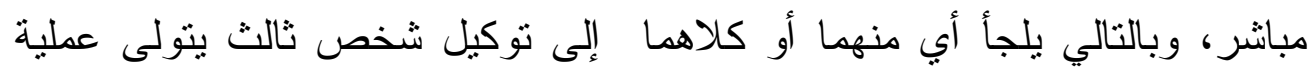

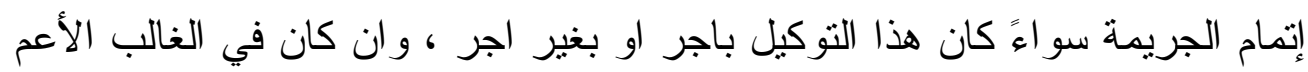

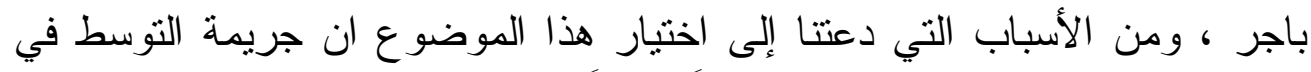

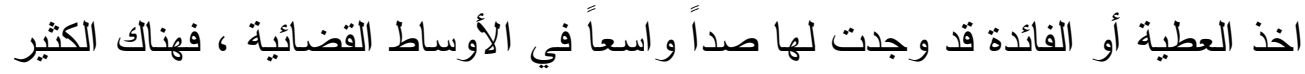

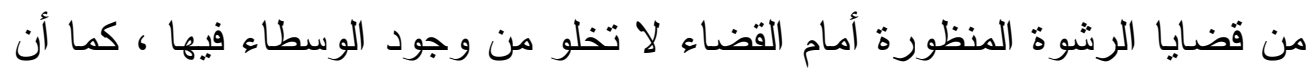

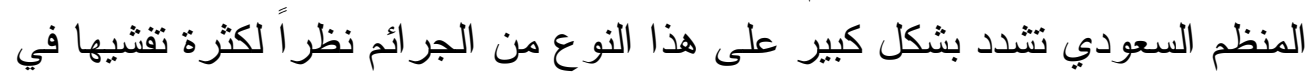

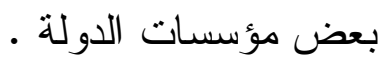
أهمية البحث.

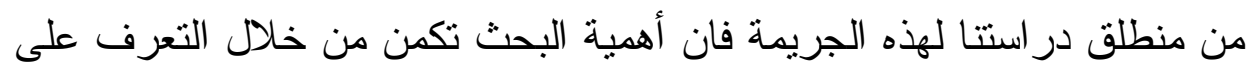

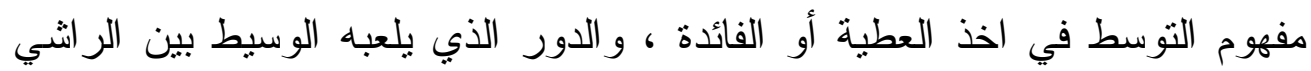

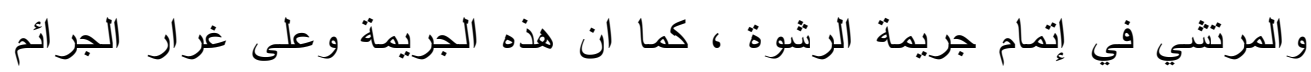

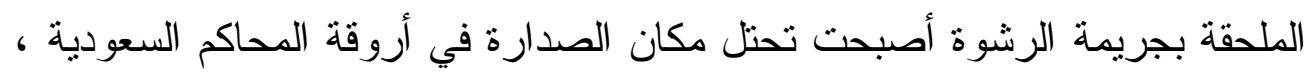

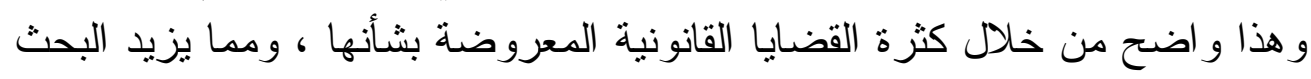

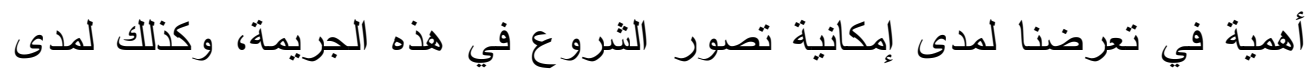

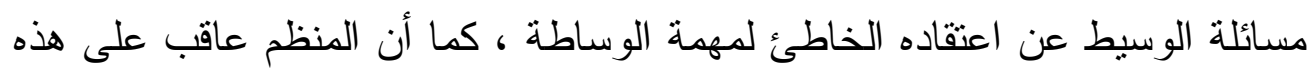




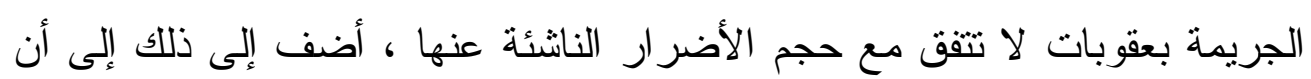

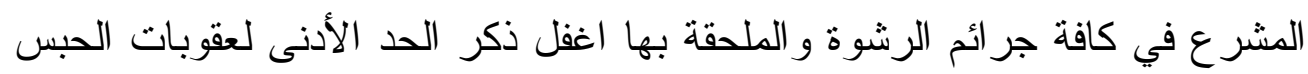
و الغر امة تاركاً المجال لتقدير القاضي حسب كل كل حالة ولة على حدة ، ونتساءل في نهاية

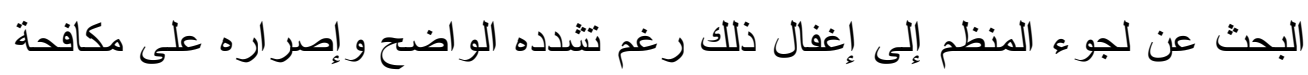
منل هذه الجر ائم ومن بينها جريمة التوسط في اخذ الفائدة أو العطية .

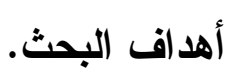

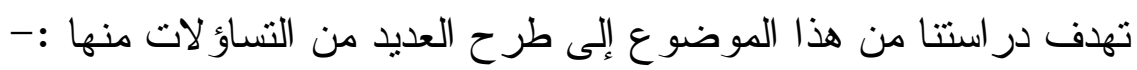
1 - ما مفهوم جريمة التوسط في اخذ العطية أو الفائدة

$$
\text { r- ما مفهوم الوسيط في هذه الجريمة }
$$

r- ما مدى اختلاف جريمة التوسط في اخذ العطية عن جريمة الوساطة في الرشوة

ع - ما العلة الأساسية التي من أجلها تتاول المنظم بالتجريم لفكرة التوسط في اخذ العطية ــ ما الأركان القانونية اللازمة لقيام جريمة التوسط T- ما مدى إمكانية تصور الثروع في هذه الجريمة

V- لماذا أطلق المنظم السعودي العنان بعدم تحديد صفة معينة للوسيط خاصة صفة الموظف العام

ᄉ- ما مدى إمكانية معاقبة المنظم السعودي للوسيط عن العلم اللاحق بجريمة التوسط.

9 - ما شكل القبول الصادر من الوسيط لقيام جريمة التوسط في أخذ الفائدة • 1ـ هل ينطلب الأمر للعقاب على هذه الجريمة أن تكون جريمة الرشوة قد وقعت فعلاً

1 ا - ما موقف الفقه القانوني من جريمة التوسط في احذ العطية أو الفائدة 


\section{العدد الثاني - الجزء الثاني - السنة التاسعة والخمسون- يوليو Vامr P}

r ا ـ ما التطبيقات القضائية التي صدرت من المحاكم السعودية بشأن جريمة

$$
\text { التوسط في اخذ العطية }
$$

با ـ ما مدى ملائمة النصوص القانونية لهذه الجريمة مع حجم الإضرار التي

تخلفها

$$
\text { صعوبات البحث. }
$$

تكمن صعوبة البحث من وجهة نظرنا في قلة المؤلفات الفقهية والمراجع

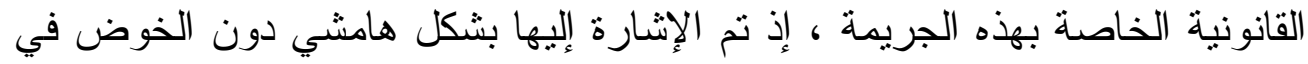

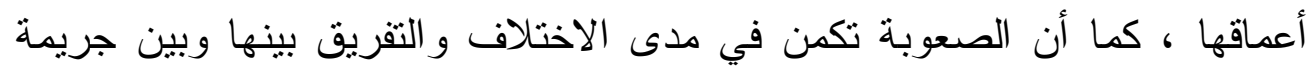

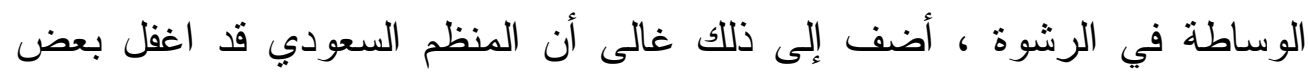

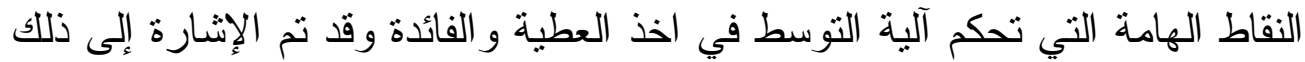

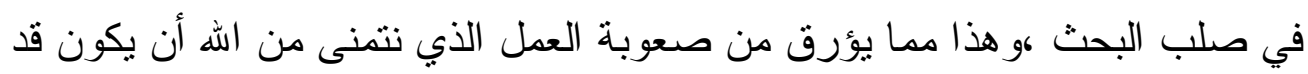
خرج ولو بشكل جزء بما يتفق وصحيح القانون خطة البحث

جاءت تسمية بحثنا ب ( الأبعاد القانونية لجريمة التوسط في أخذ العطية أو الفائدة وفقاً للنظام الجزائي السعودي) وقد تم تقسيمه إلى مبحثين رئيسيين بعد مقدمة عامة ، وذللك على النحو الآتي: المبحث الأول الماهية القانونية لجريمة التوسط في اخذ العطية او الفائدة المطلب الأول ماهية التوسط في اخذ العطية أو الفائدة أو لاً: - مفهوم الوسيط في جريمة التوسط ثانياً:- - فكرة التوسط في اخذ العطية او الفائدة

$$
\text { ثالثاً:- العلة من تجريم التوسط }
$$

ر ابعاً:- مدى وقوع جريمة الرشوة كعقاب للوسيط في التوسط .

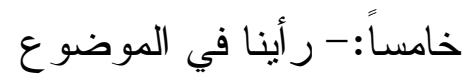

المطلب الثاني :- الأركان القانونية لجريمة التوسط في اخذ العطية او الفائدة.

$$
\text { أولاً:-- الركن الثرعي لجريمة التوسط }
$$




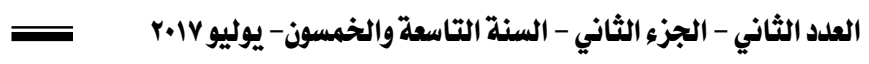

$$
\begin{aligned}
& \text { ثانياً:-- الركن المادي } \\
& \text { ثنالثاً:- الركن المعنوي } \\
& \text { رابعاً:-- العقوبات الجنائية }
\end{aligned}
$$

المبحث الثاني فرضيات الدر اسة بشأن جريمة التوسط في أخذ العطية او الفائدة المطلب الأول مدي مسائلة الوسيط بصفته موظفاً عامًاً المطلب الثاني مدى علم ومو اققة الموظف كأساس لعقاب الوسيط المطلب الثالث مدى عقاب الوسيط على العلم اللاحق لقبوله مهمة الوساطة المطلب الر ابع مدى تصور الثروع في جريمة التوسط التتائجج و التوصيات المر اجع 


\section{البمشث الأول}

\section{الماهية القانونية لهريمة التوسط في أفذ العطية أو الفائدة}

صدر نظام مكافحة الرشوة السعودي بموجب المرسوم الملكي رقم م/ جآب

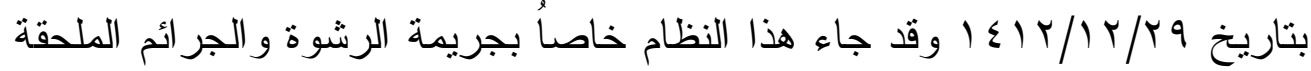

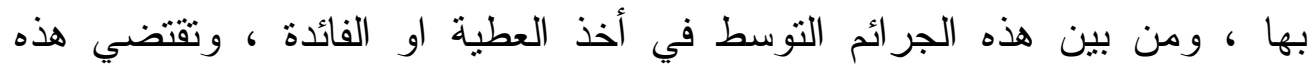
الجريمة قيام شخص ثالث وهو الوسيط بأعمال توسطية غير مشروعه جلها تقريب

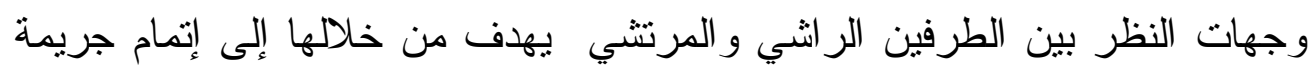

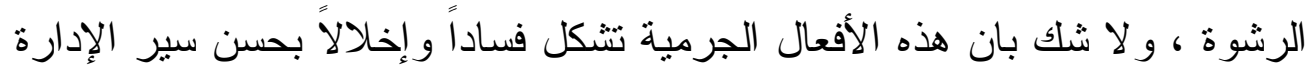

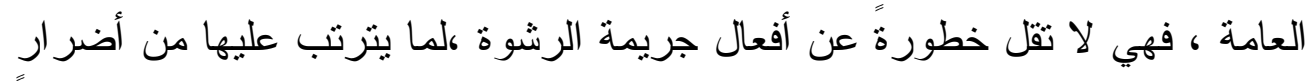
و إخطار بحسن سير العمل الوظيفي ، و عليه سنتولى بيان ماهية هذه الجريمة وفقاً لهذا المبحث في المطالب الآتي:-

\section{J الأل}

\section{مافية التوسط في اخذ الهمية أو الفائدة}

أولاً: مفهوم الوسبط في جريمة التوسط

نصت المادة الحادي عشر من نظام مكافحة جريمة الرشوة السعودي عل أن أن ( كل شخص عينه المرتني أو الر اثني لأخذ الرشوة وقبل بذلك مع علمه بالسبب يعاقب

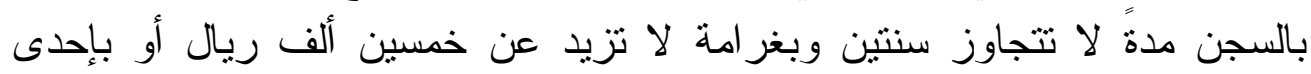
هاتين العقوبتين)' و عليه لم يتعرض المنظم السعودي لبيان مفهوم الوسيط في هذه الجريمة ، وكل

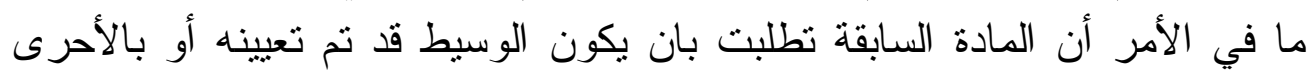

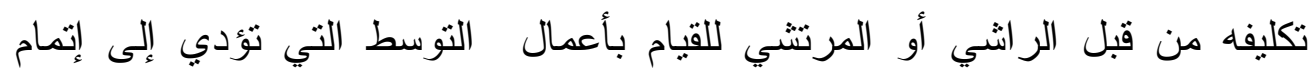

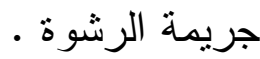

ومن وجهة نظرنا فان الوسيط هو "ذلك الثخص الذي يتم تكليفيه أو تعيينه من

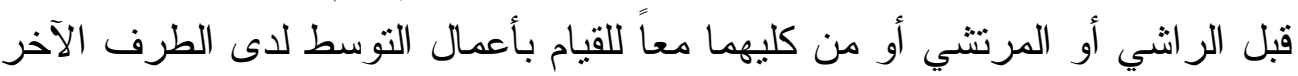

' المادة 11 1 من نظام مكافحة جريمة الرشوة السعودي الصادر بالمرسوم الملكي م/؟ب بتاريخ $.1 \leqslant / r / K / Y q$ 


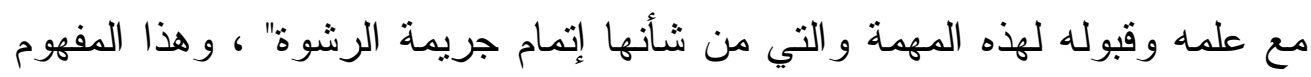

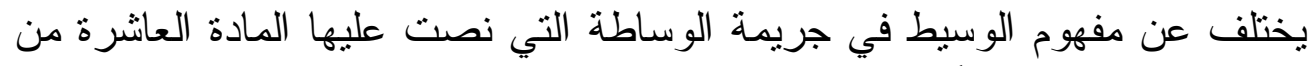

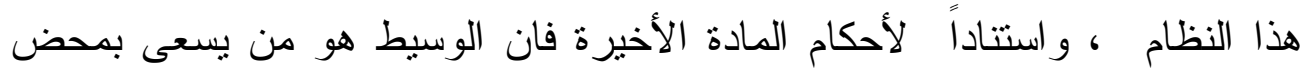

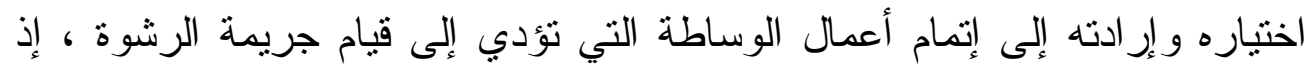

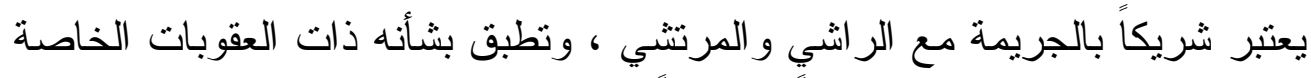

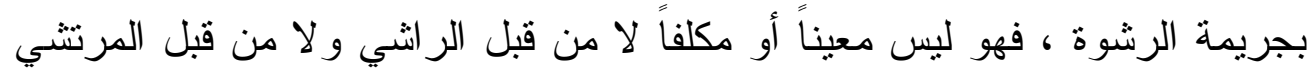
كما هو الحال في جريمة التوسط في اخذ العطية أو أو الفائدة.

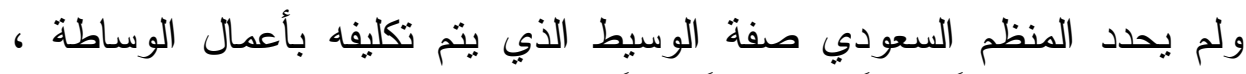

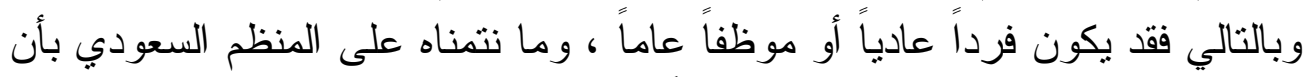

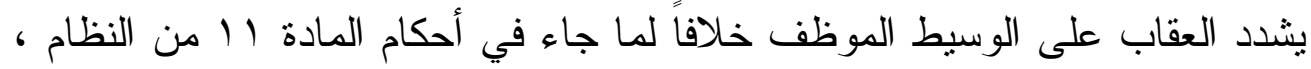

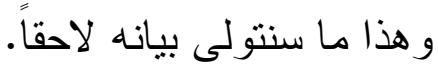
ثانياً: العلة من تجريم التوسط في الخفا.

لعل الاحتكام للقو اعد العامة تُظهر العلة الأساسية التي من أجلها لجأ الدنظم

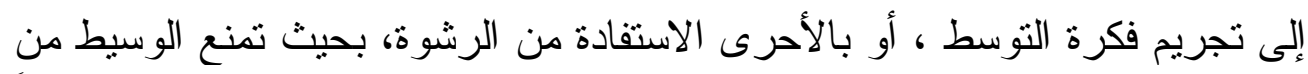

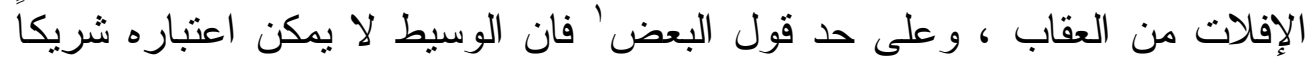

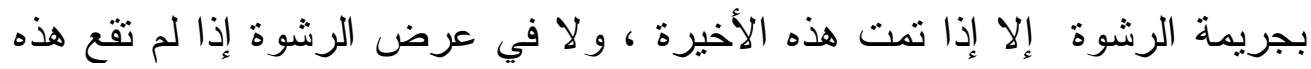

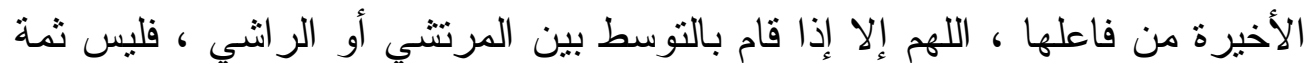

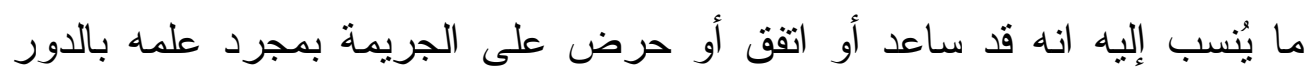

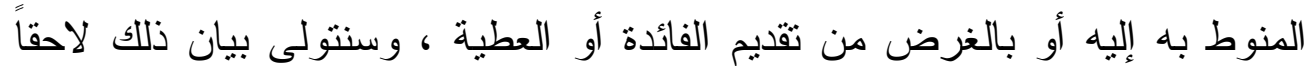

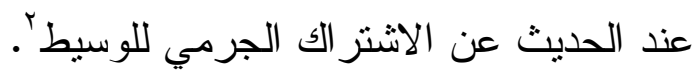

' د. كامل السعيد ، شرح قانون العقوبات ، القسم الخاص، الجر ائم المضرة بمصلحة الدولة، دار

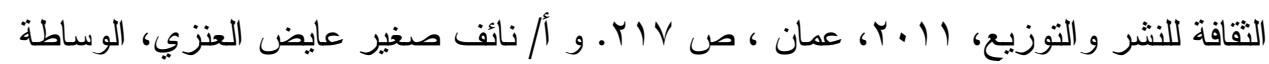
في الرشوة في النظام السعودي، در اسة تأصيلية تطبيقية، رسالة ماجستير ، كلية العدالة الجنائية،

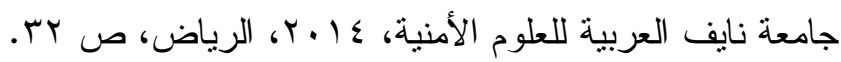

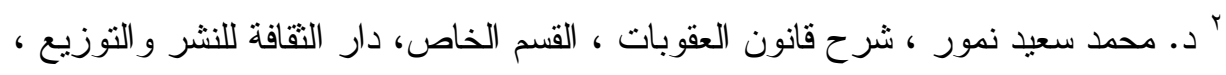

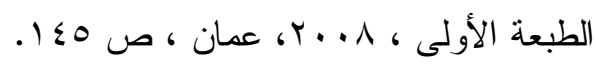


ولكن ورغبةً من المنظم السعودي في مو اكبة السياسة التشريعية وما تتطلبه من مقتضيات تتفق وصحيح القانون فقد ارتأى المنظم إلى ملاحقة الوسيط بعقابه جز ائياً

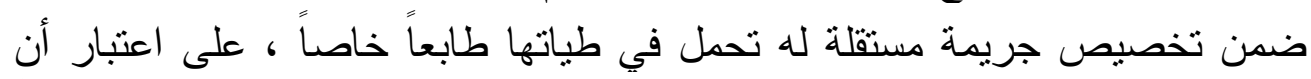

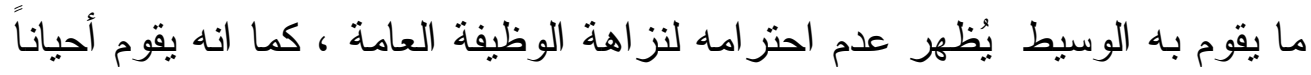

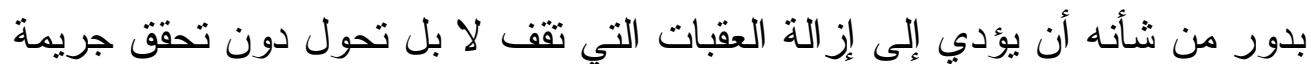

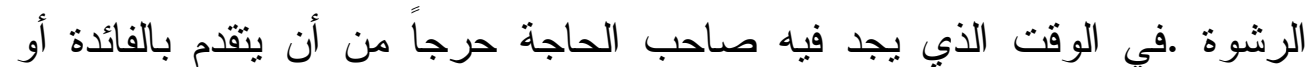

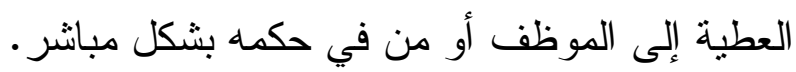

ثالثاً: التوسط في أخذ الفائدة ومدى تصور الاثتر الك الجرمي للوسيط

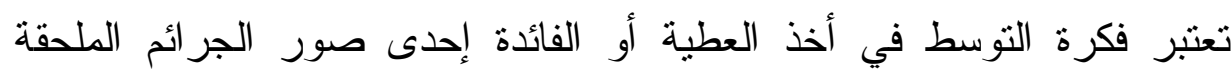

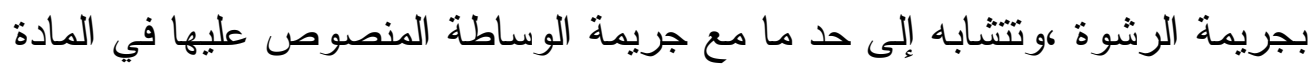

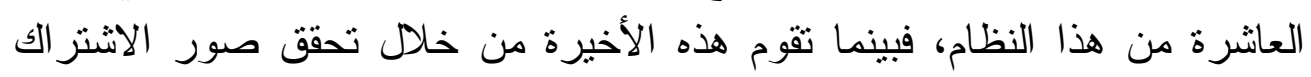

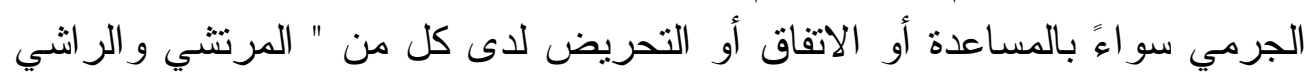

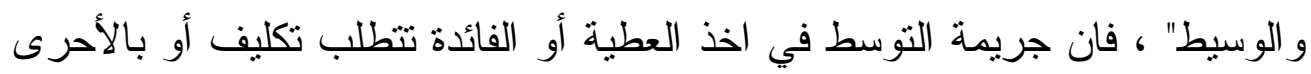

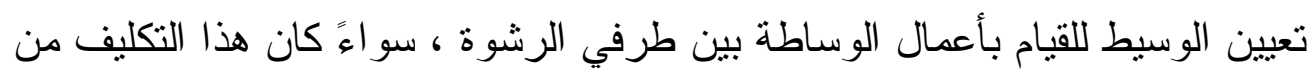

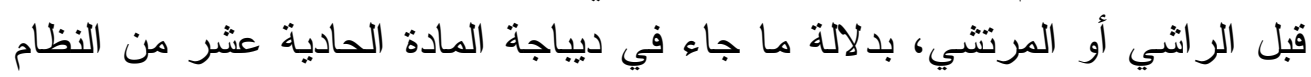

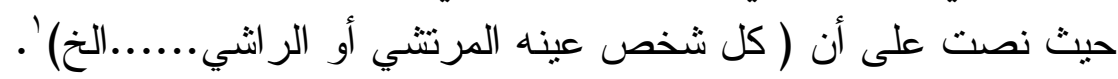

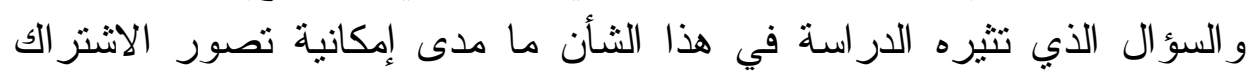

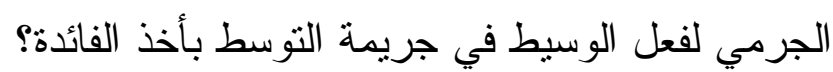

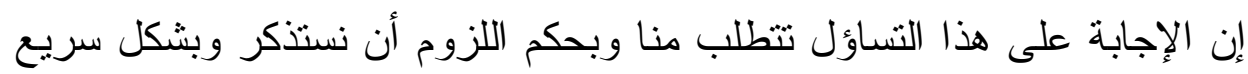

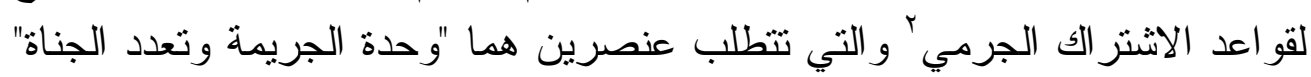

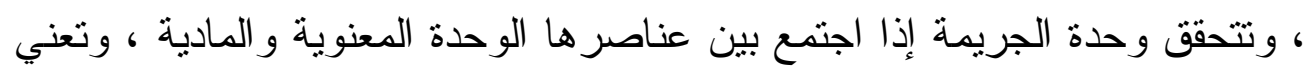

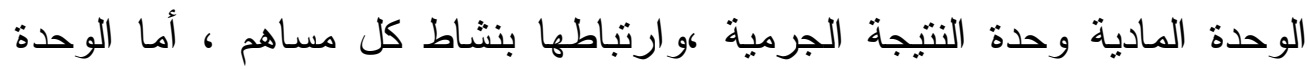

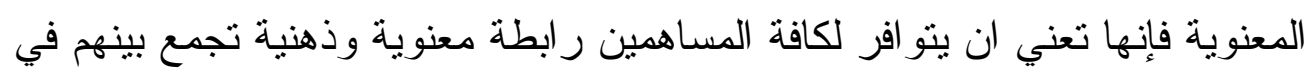

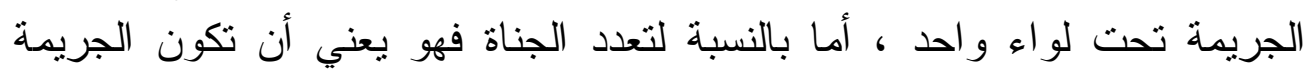

' راجع المادة 11 1 من نظام مكافحة الرشوة السعودي سبق الإثشارة إليها.

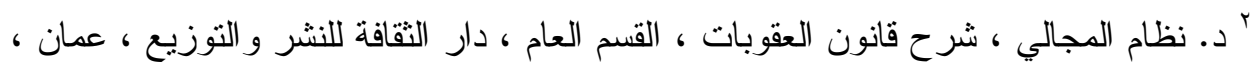

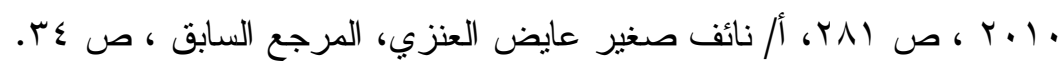


الو احدة قد ساهم في تتفيذها أكثر من شخص على نحو يمكن القول بان هنالك تعدد في الأشخاص بشأن ارتكابهم لجريمة و احدة.

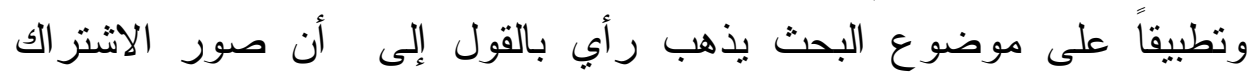
الجرمي تتو افر في جريمة المادة العاشرة وغير متوافرة في جريمة التوسط ، فالمنظم قد حدد صور الاشتز الك لجريمة الوساطة بشكل و اضح وصريح بموجب أحكام المادة العاثرة ، في حين ان صور الاشتر الك في جريمة التوسط غير متو افرة

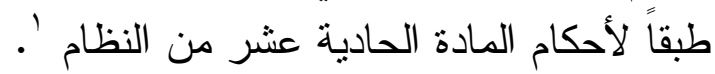
و من وجه نظرنا المتو اضعة نقول انه إز اء عدم وضوح المنظم في مدى اعتبار أعمال الوسيط من قبل الاثتر الك الجرمي فان القو اعد العامة تقضي باعتبار الوسيط شريكاً إذا تمت جريمة الرشوة ، كما ويعتبر شريكاً في جريمة عرض الرشوة إذا فأ وقعت هذه الأخيرة من فاعلها ، وبتطبيق قو اعد الاشتر اك الجرمي نرى بتو افرها بحق الوسيط في هذه الجريمة ، فالوسيط يساهم في تتفيذ الركن المادي للجريمة ، كما و انه تزبطه مع المساهمين رابطة ذهنية ومعنوية لإتمامها ، مع أننا نميل في ذات الوقت بمعاقبة الوسيط في جريمة التوسط بذات العقوبات المقررة لكل من الر اشي و المرثتي في جريمة الرشوة ، و اعتبار أعمال التوسط في أخذ الفائدة أو العطية من صور الاشتز الك الجرمي بغض النظر عن وقوع الرشوة أو ما يلحق بها من جرائم ، نظر اً لفداحة الأضر ار الناتجة عن هذا الجريمة ، وبدلالة تطلب المنظم لقيام هذه الجريمة مجرد علم الوسيط و القبول بهذه المهمة الدنيئة.

\section{رابعاً: مدى وقوع جريمة الرشوة كعقاب للوسيط في التوسط .}

تباينت آراء الفقهاء حول مصبر عقاب الوسيط إزاء ما يقوم به من أعمال التوسط ، حيث ذهب البعضَ منهم إلى أن وقوع جريمة الرشوة يعتبر شرطاً

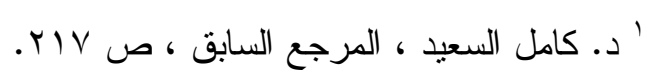

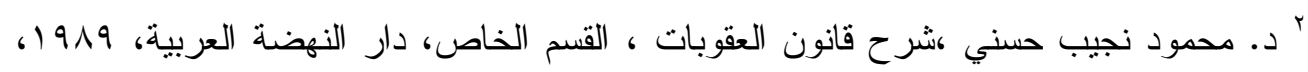
ص 0 ا r. ود. عبدالعظيم وزير ، القانون الجنائي الخاص ، جريمة الرشوة واستغلال النفوذ، دار النهضة العربية ، دون تاريخ نشر ، ص بـا ود. فوزية عبدالستار ، شرح قانون العقوبات ،

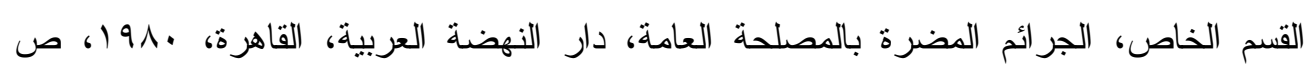




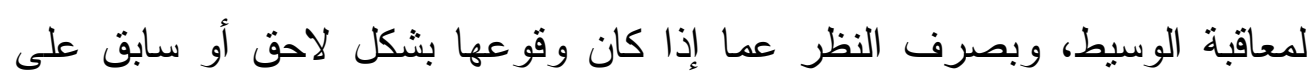

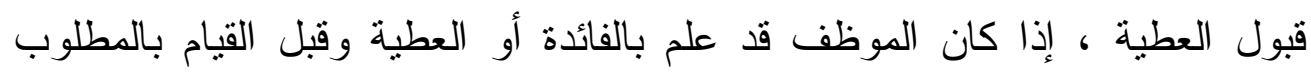
نظير ذلك ، و على العكس فان الموظف إذا تو افر لديه العلم بتقديم المقابل إلا انه لم لم إلمان

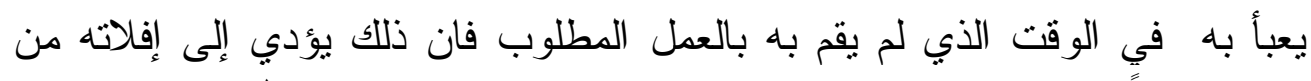

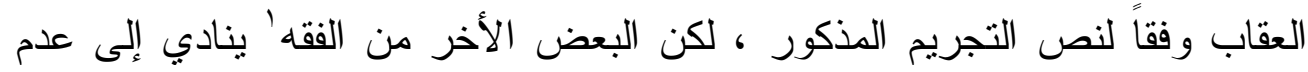

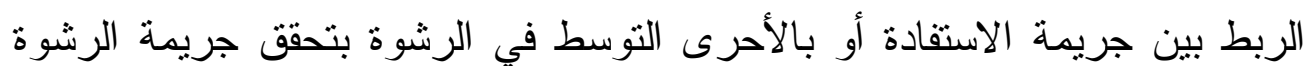

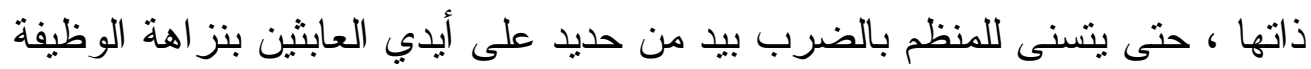

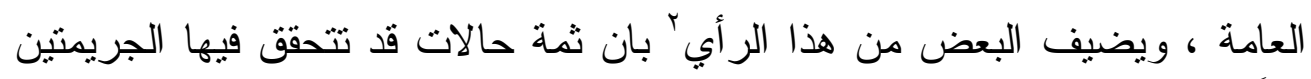

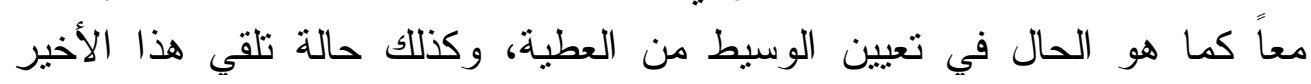
للعطية دون ان يتو افر علم الموظف بذلك ، لكن هذا الأخير بعد أن تو افر لديه العلم

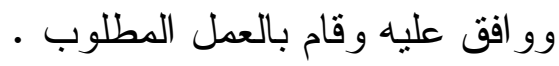

على أية حال لا بد من التتويه إلى أن هذا الاختلاف قد يكون راجع إلى كثرة

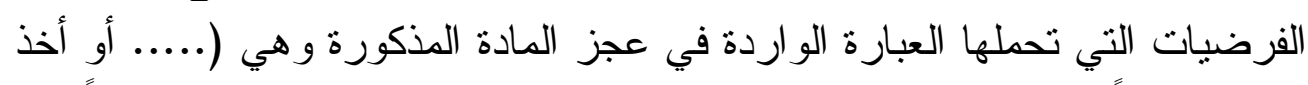

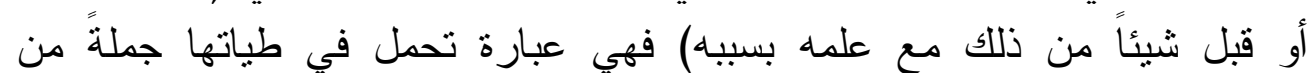

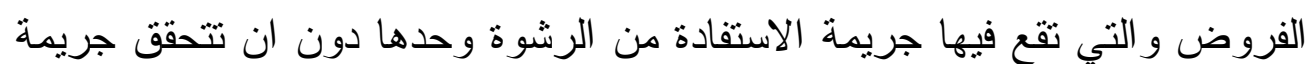

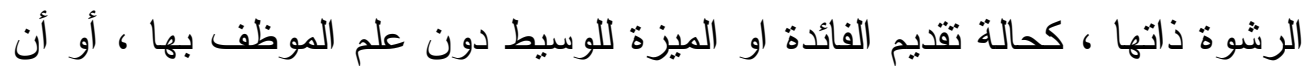

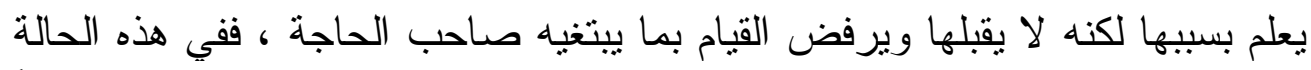
فان الوسيط يكون قد أخذ العطية مع علمه بسبب تقديمها ، وبالتالي فيكون مستحقاً

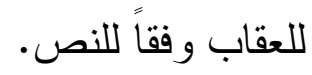

' د.طه عثمان مغربي ود. محمد عبدالرحمن عبدالمحسن ، النظام الجزائي الخاص في المملكة

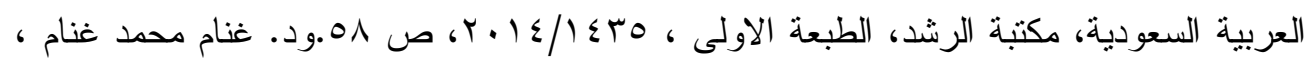

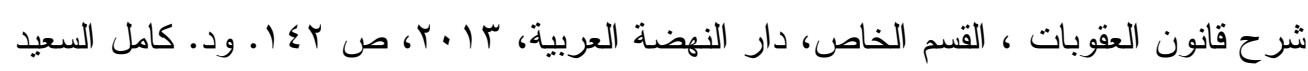

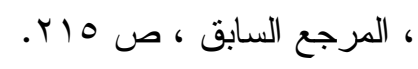

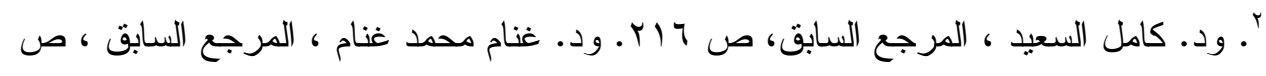


كما ويذهب البعض' بأنه لا مجال للقول بتو افر المسؤولية على الوسيط إذا لم

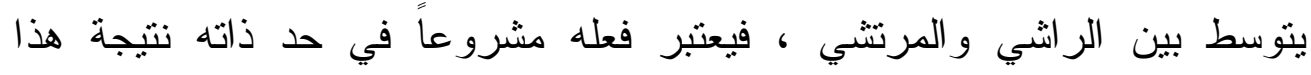

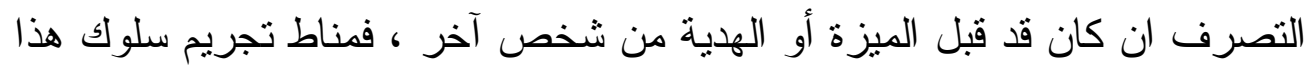

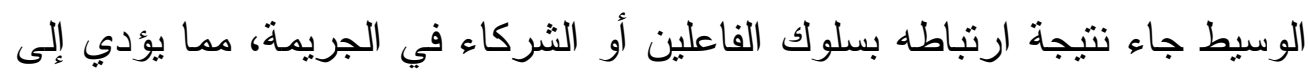

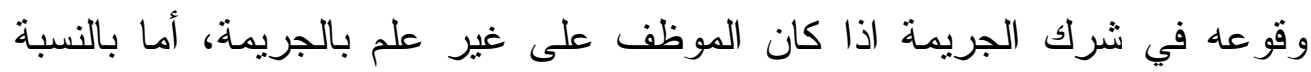

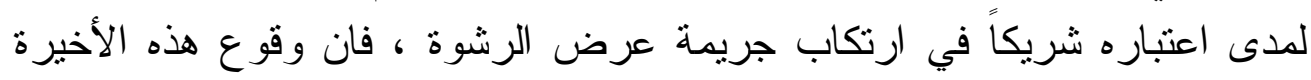

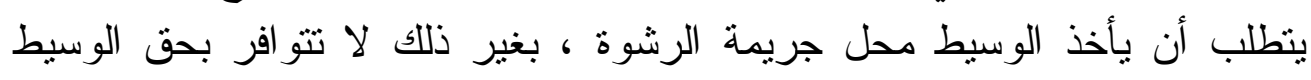
جريمة التوسط في عرض الرشوة.

\section{خامساً: رأينا المتو اضع}

ومن وجهة نظرنا المتو اضعة فإننا نميل إلى مشايعة الر أي الثاني في ذهب إلبه

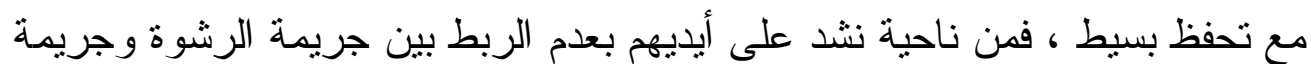

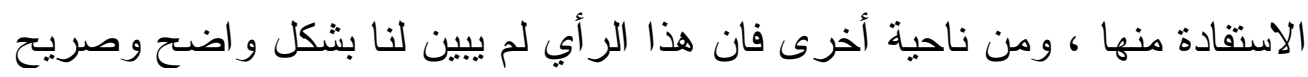

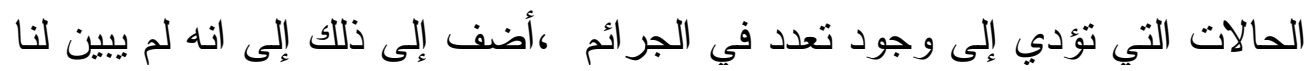

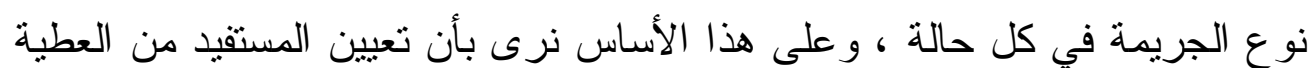

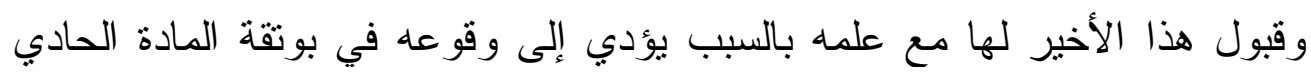
عشر من النظام ، حتى ولو لم يقم بالعمل المكلف به كما ذكرنا أنفاً، أما بالنسبة المادية

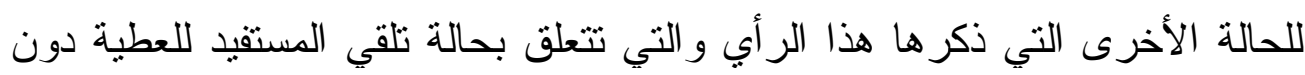

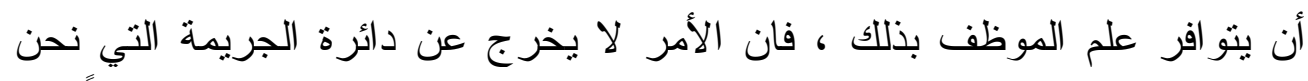

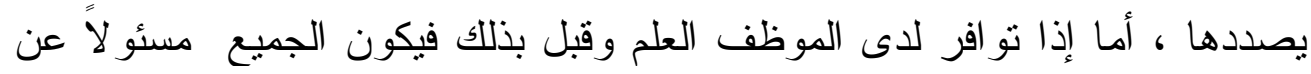

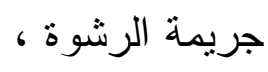

وتفنيداً منا على ما جاء في الر أي الأول فإننا نرى فيه "مع احتر امنا الثديد له"

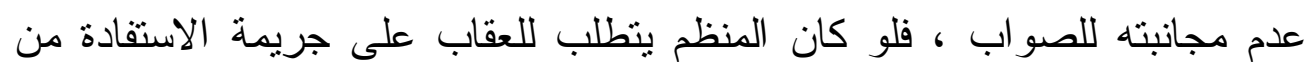

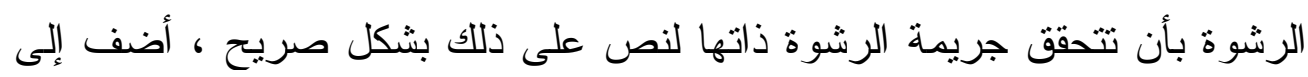

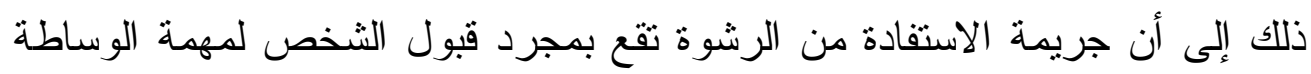

' د. عبدالحكم فودة، الموسوعة الجنائية الو فية في النطبيق على قانون العقوبات، دار الفكر

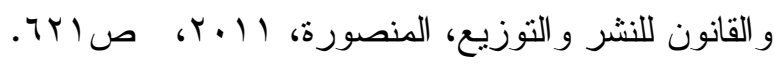


مع علمه بالسبب سو اءً تم تكليفه من قبل المرتشي ام من قبل الراثي، وسواء قام الوسيط فعلياً بالعمل المنوط به أم لم يقم ، وهذا القول يكفي في حد ذاته لمديل لمسائلة

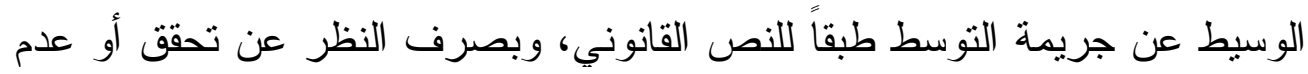

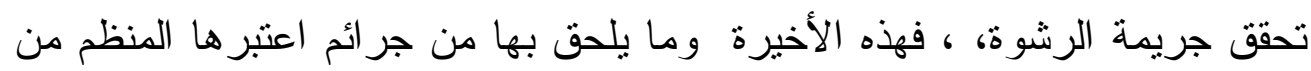

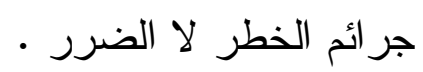

وبمعنى أكثر وضوحاً وتعدداً منا للتحليل أكثر فأكثر فان الوسيط المستقيد يفلت

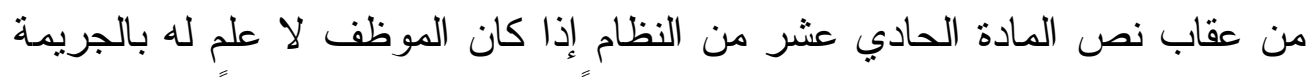

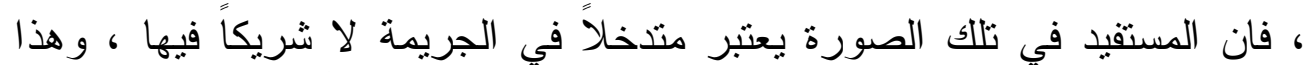

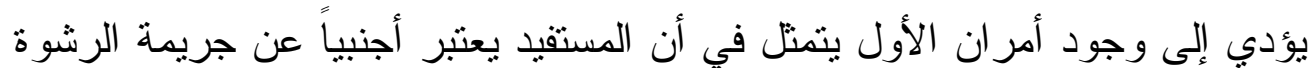

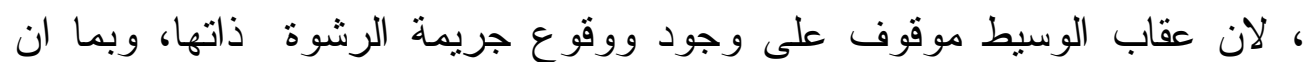

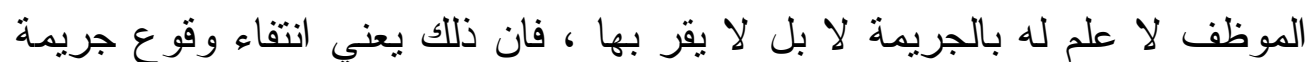

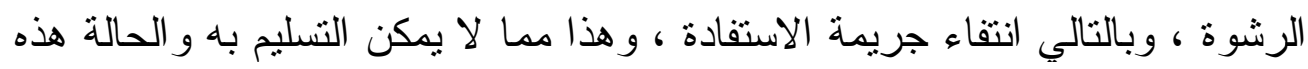

على أية حال قد تنو افر جريمة عرض الرشوة أن تو افرت أركانها ، و وعلى ذلك

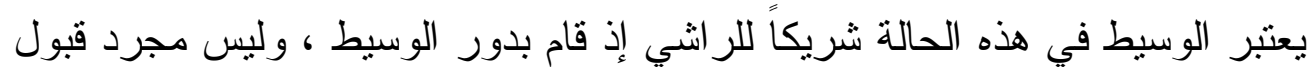

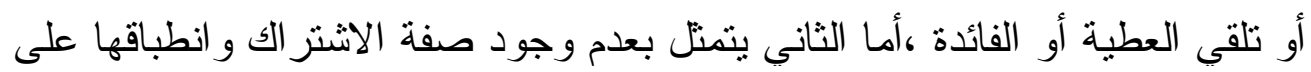

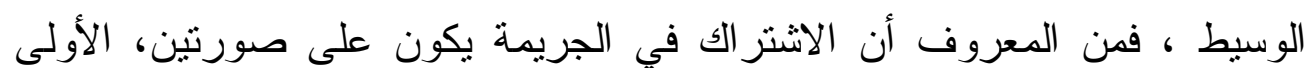

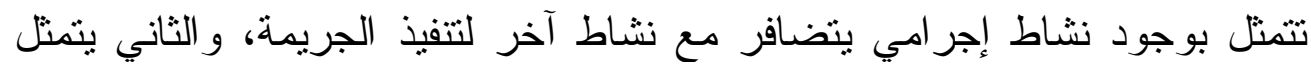

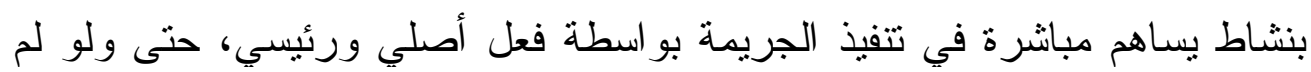

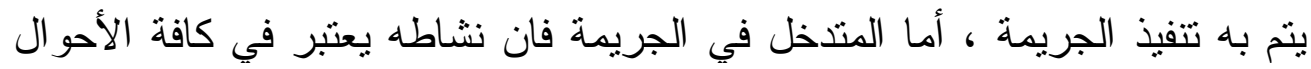

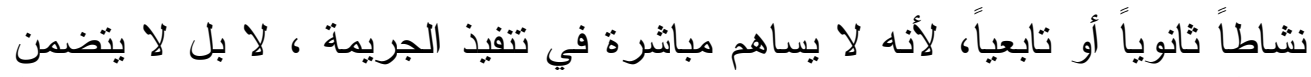

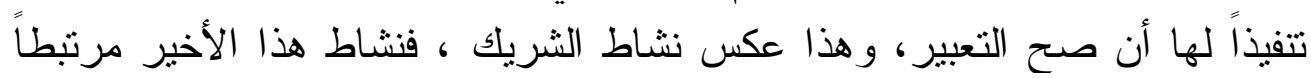

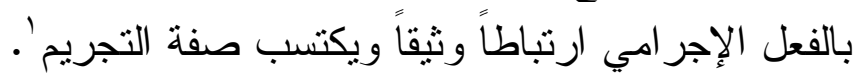

' د. محمد زكي أبو عامر ، ود. علي عبدالقادر القهوجي، قانون العقوبات اللبناني ، القسم العام،

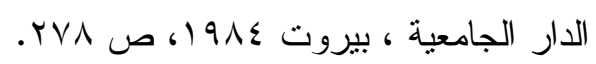




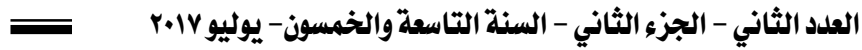

على أية حال فان الواقع العملي يشهح بان أكثر حالات التكليف بالقيام بأعمال الوساطة تقع من جانب الموظف العام المرتشي نتيجة لأعماله الوظيفية التي يحتاجها الغير، حيث يلجأ هذا الأخير بطريقة غير مشروعه بتكليف احد الأشخاص لإعلان رغبته بالمتاجرة بأعمال الوظيفة العامة.

وتطبيقاً على ذلك فقد أدانت المحكمة الإدارية بمحافظة جدة شخصاً لقيامه بأعمال توسطية بين الر اثي و المرتني ، ومما جاء في حيثيات الحكم انه (فقد أقام

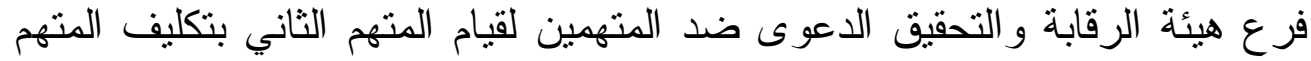
الأول بالتوسط في جريمة الرشوة بينه وبين المخبر بأن استلم مبلغ الرشوة من فن

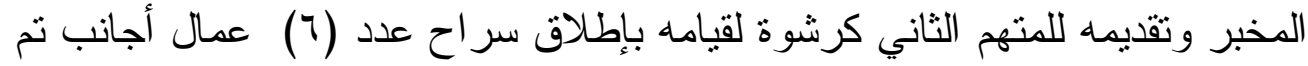
القبض عليهم كونهم لا يعملون تحت كفالة المخبر ، ولقيام المتهم الثاني حال كونه

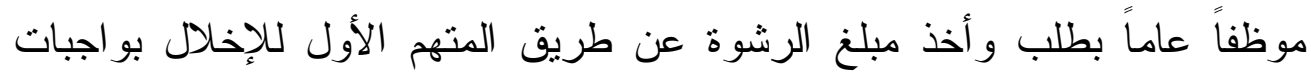

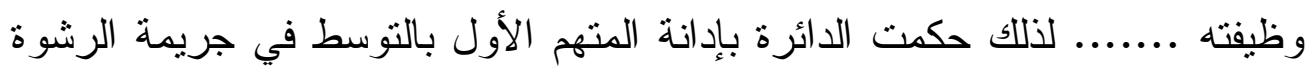

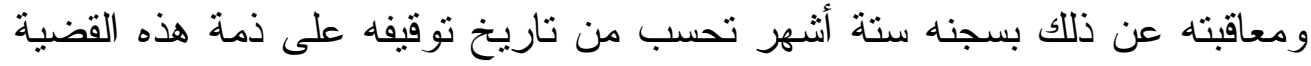

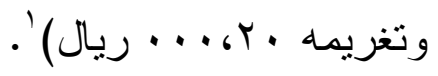

\section{الإطابب الثاني}

\section{الأركان القانونية لبهريمة التوسط في اخذ العطية او الفاثدة}

يذهب البعض من الفقهُ إلى أن الجريمة لا بد من أن يتو افر بها ثلاثة أركان

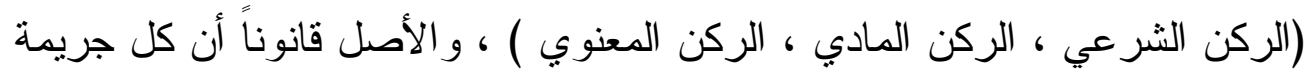

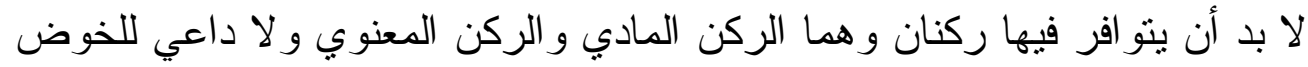

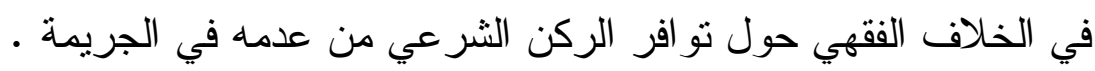

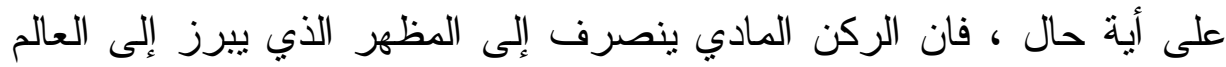
الخارجي وهو تجسيد لماديات الجريمة ، وله ثثلاثة عناصر أساسية وهي ( السلوك ،

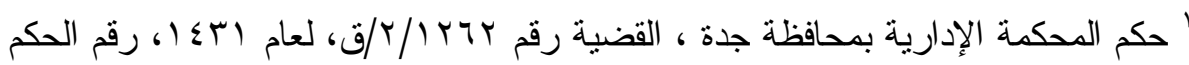

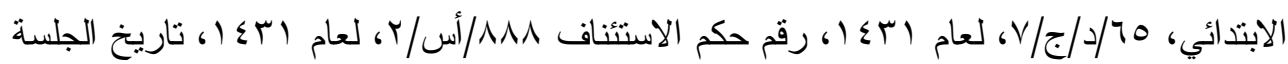

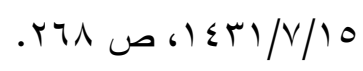

${ }^{2}$ Pradel (Jean): Manuel:de droit penal special. Paris ، Cujas، 200.p254.. 
النتيجة ، علاقة السبيية) ، فالسلوك او ما يعبر عنه بالفعل الإجرامي هو ذلك

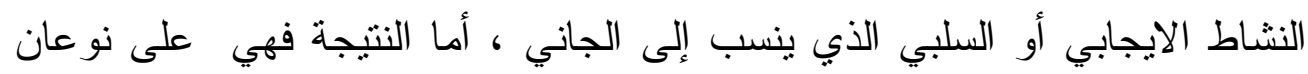

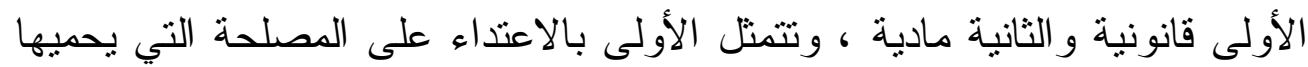

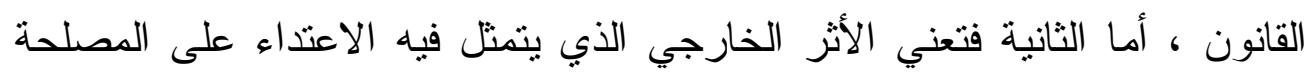

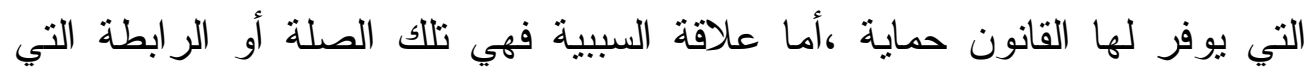

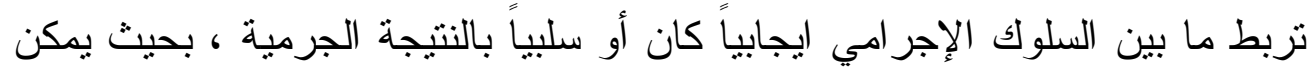

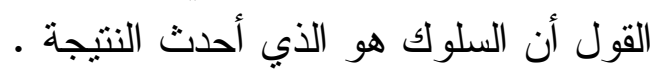
أما الركن المعنوي هو حالة نفسية تقترن فيها الإرادة بالفعل سواءً اتخذت التهاء

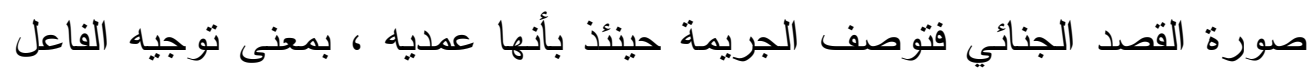
إرادته إلى ارتكاب الفعل المكون للجريمة بحيث يكون هدفه تحقيق النتيجة

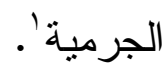

وفيما يتعلق بموضوع البحث ، فان جريمة التوسط في أخذ العطية أو الفائدة

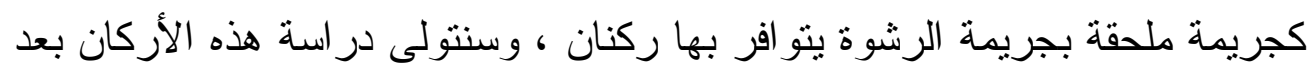
أن نبين لمفهوم الركن الثرعي وذللك على النحو الأتي:أولاً:- الركن الشرعي لجريمة التوسط (نص التجريم).

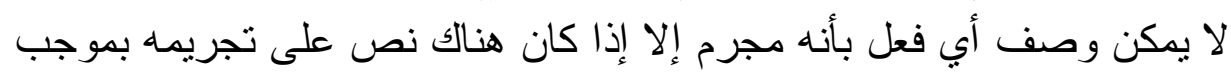

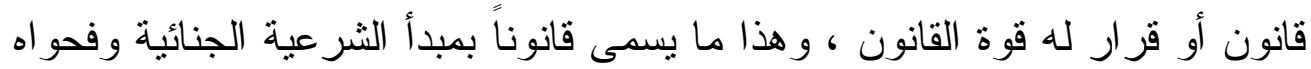

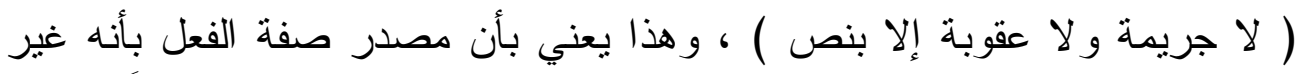

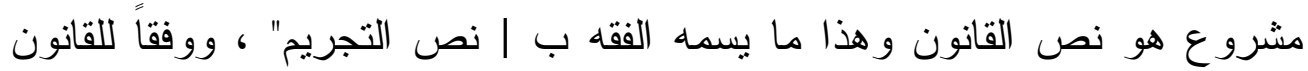

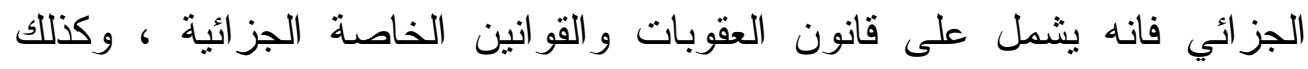

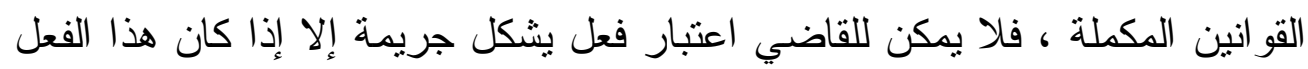

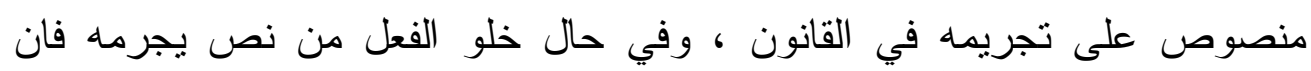

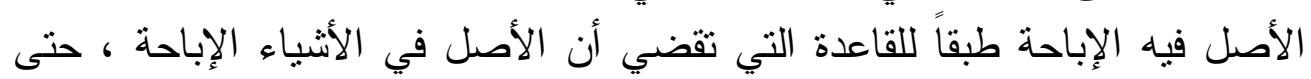

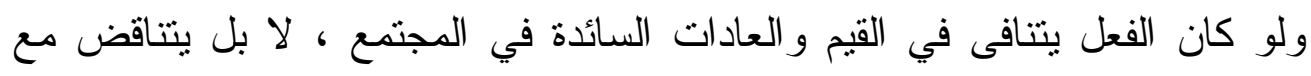

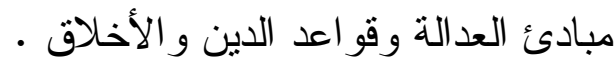

' د. كامل السعيد ، شرح قانون العقوبات ، القسم العام، دار الثقافة للنشر و التوزيع ، الطبعة

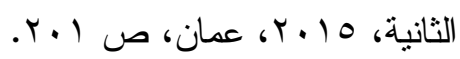


وتطبيقاً على موضوع البحث فقد جاءت المادة الحادي عشر من نظام مكافحة الرشوة السعودي تتص بشكل و اضح وصريح على معاقبة كل من يتوسط بين

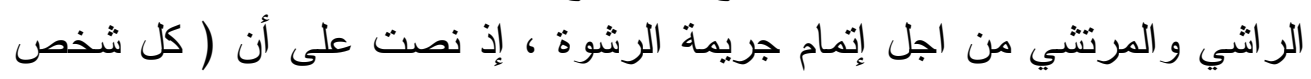

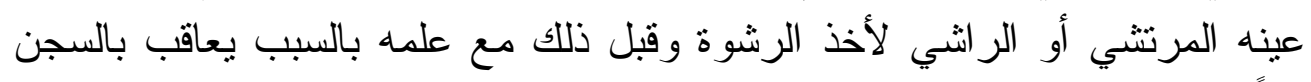

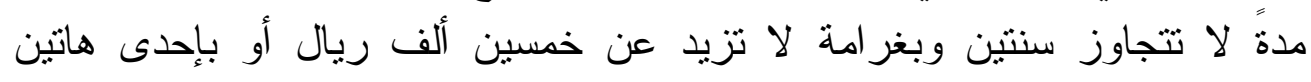

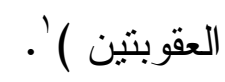

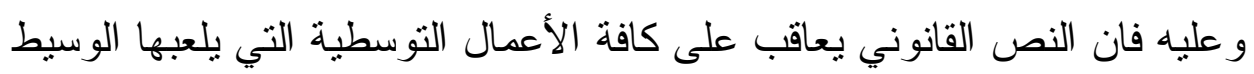

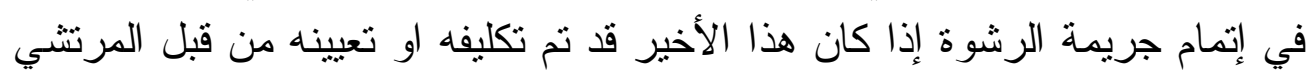

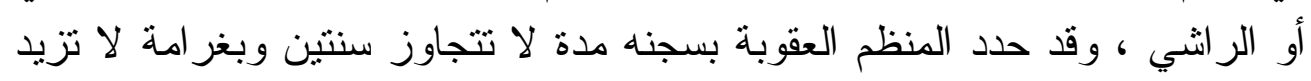

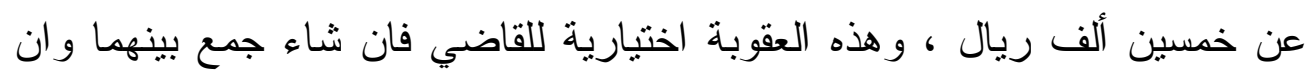
شاء حكم بو احدة منها.

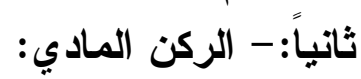

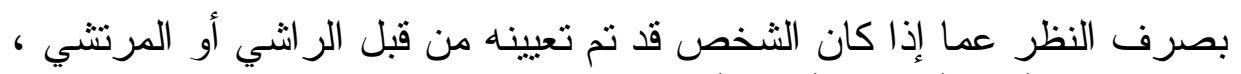

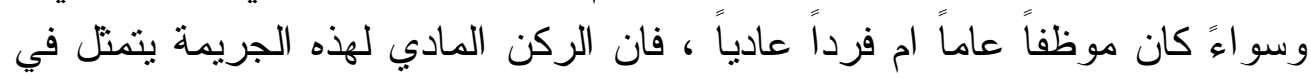

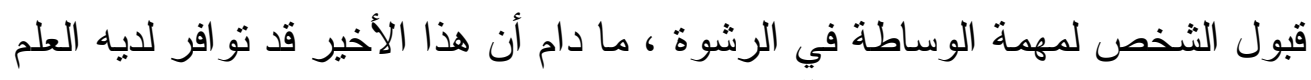

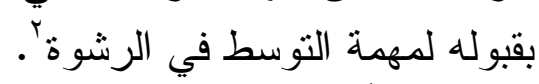
وتطبيقاً لذلك فقد أدانت هيئة التحقيق بمنطقة مكة المكرمة شخصاً بقيامه بأعمال التوسط ومما جاء في حيثيات الحكم ( ... وحيث ان المتهم الثاني قبل بالقيام بأعمال

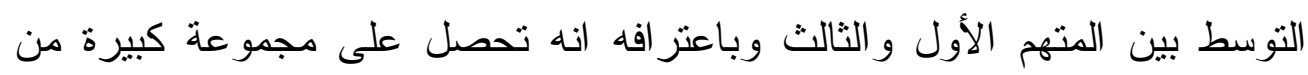

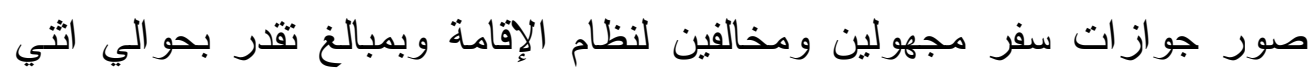

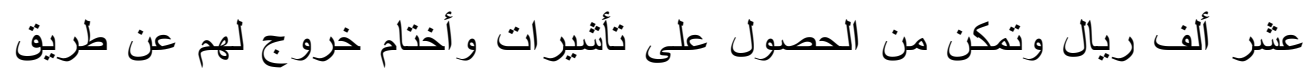

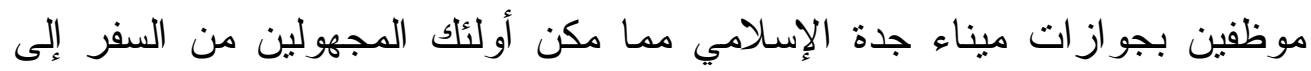

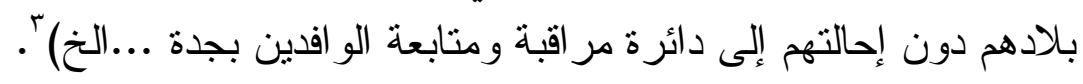

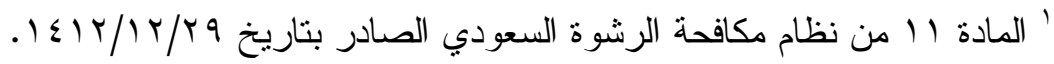

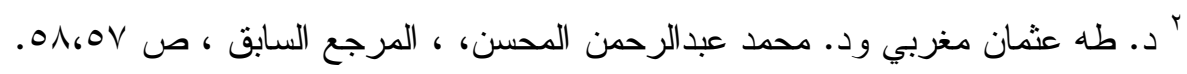

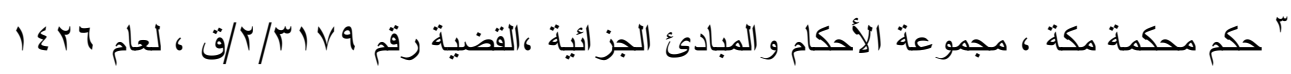

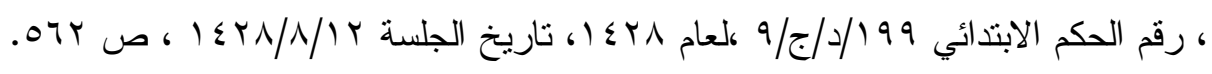


وفي جريمة التوسط فانه لا عبرة بشكل محل الجريمة سواءً كانت مادية أم

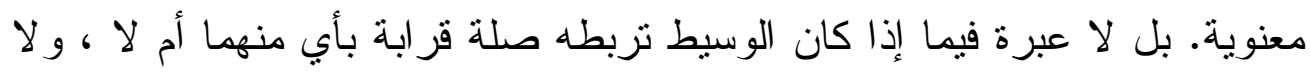

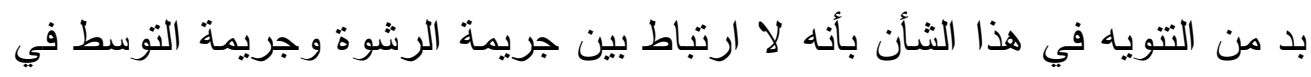

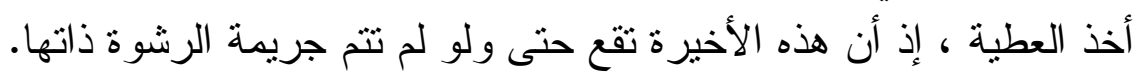

و استتاداً لنص المادة الحادية عشر من النظام ، فان الأصل في جريمة التوسط

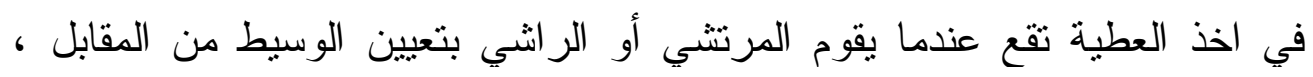

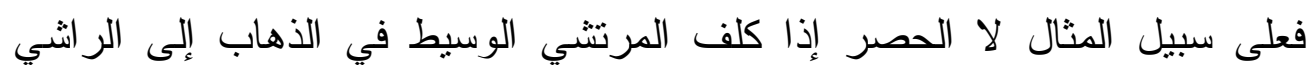

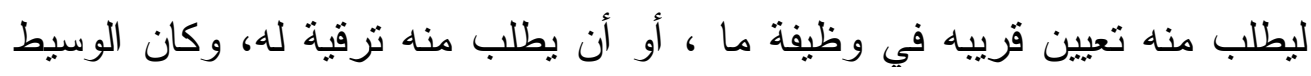

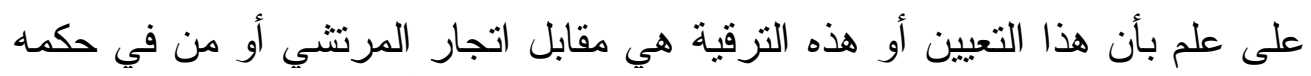

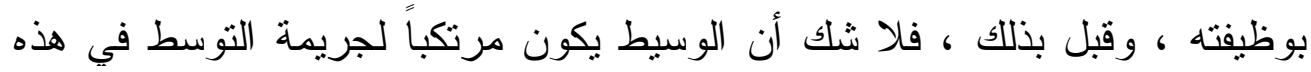

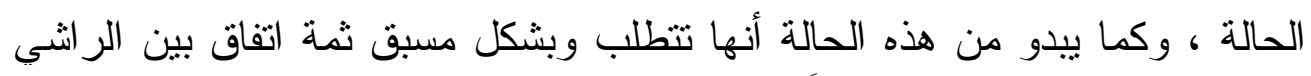

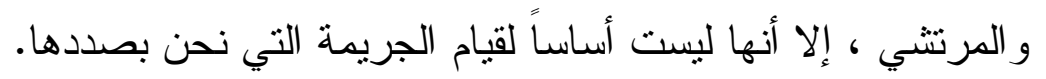

ومما نلاحظه في نص المادة 11 ، أنها تطلبت عنصر اً من عناصر الركن

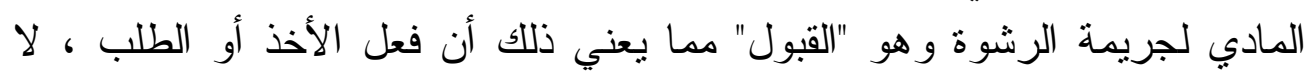

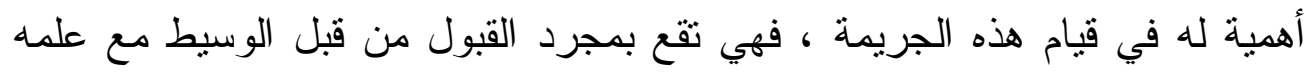

وتطبيقا على ذلك أدان فرع هيئة الرقابة و التحقيق بمنطقة عسير شخصاً عينه

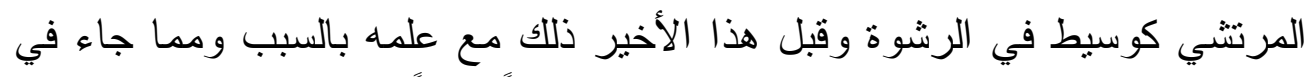

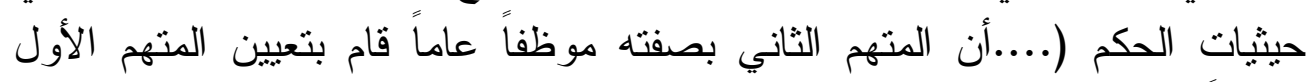
وسيطاً بينه وبين المواطن ..... لقبض واخذ مبلغ الرشوة وهو عشرة آلاف ريال

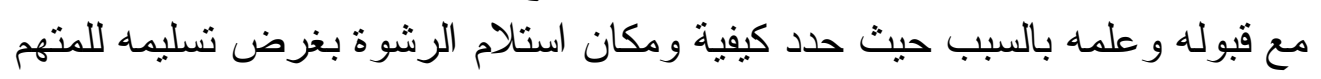

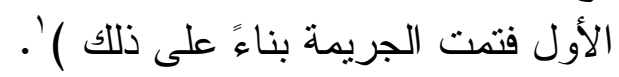

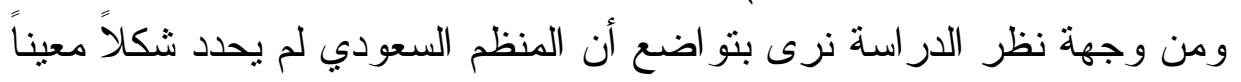

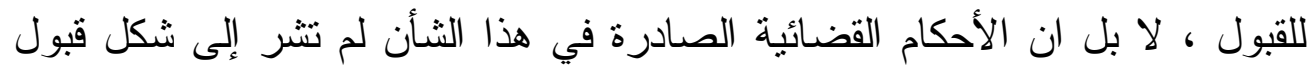

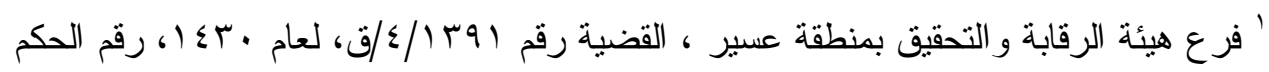

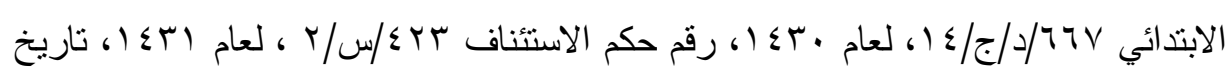

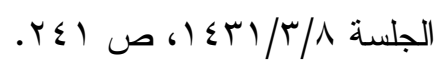


الوسيط للقيام بمهمة الوساطة ، وعليه فان الأمر بحتكم إلى القو اعد العامة ما دام

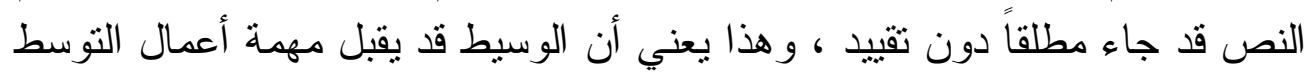

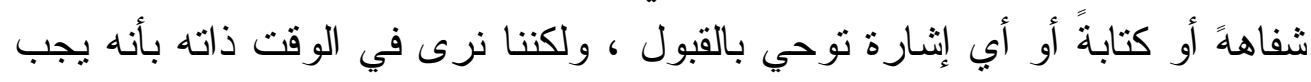

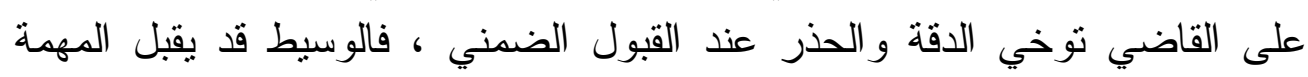

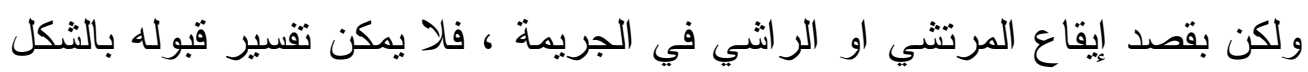

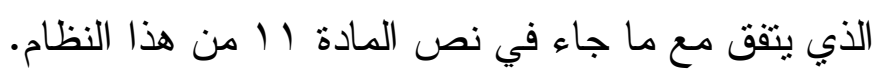

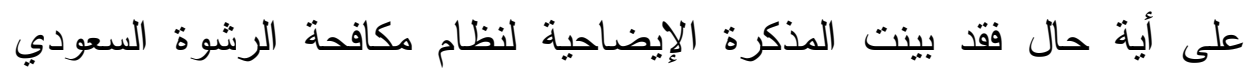

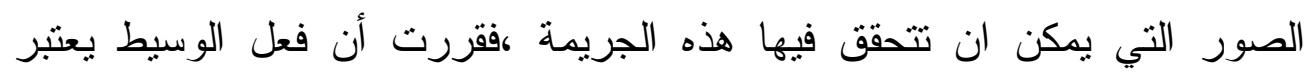

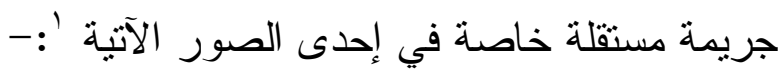

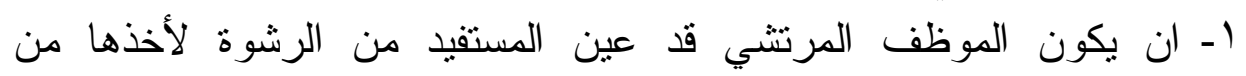

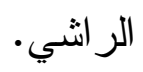

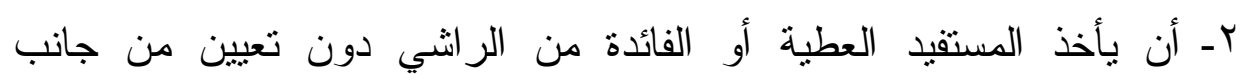

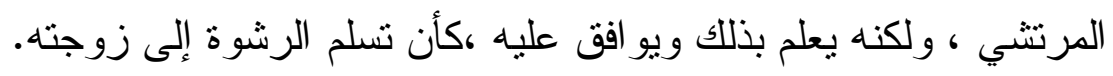

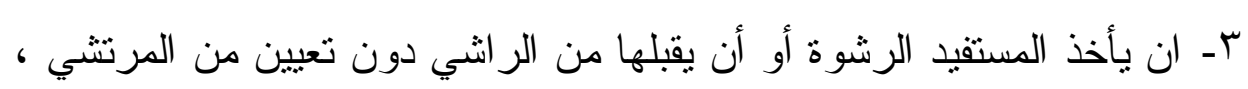

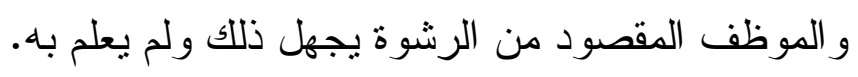

وترتيباً على ما سبق فان جريمة التوسط في أخذ العطية أو الفائدة كجريمة

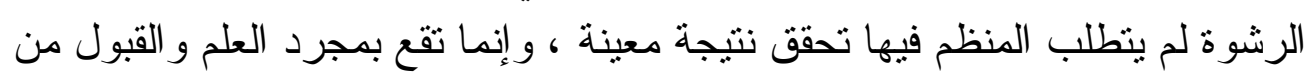

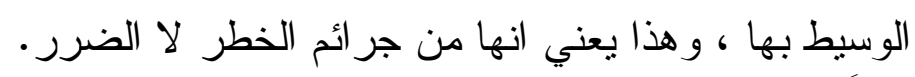
ثالثاً:- الركن المغنوي لجريمة التوني التوسط في في أخذ العطية أو الفائدة.

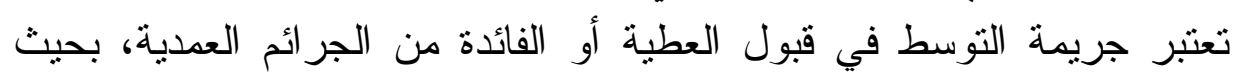

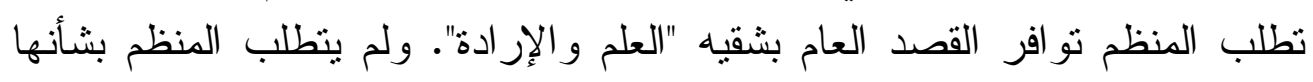

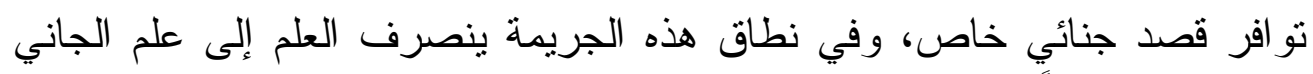

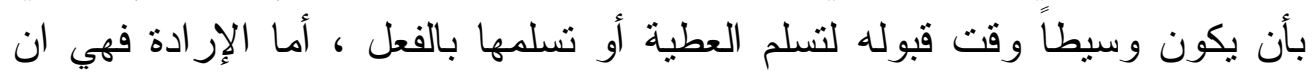

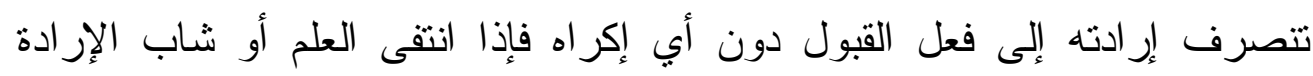
' د. طه عثمان المغربي ود. محمد عبدالرحمن المحسن، المرجع السابق، ص OV. 


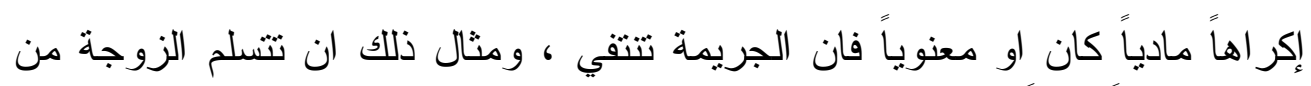

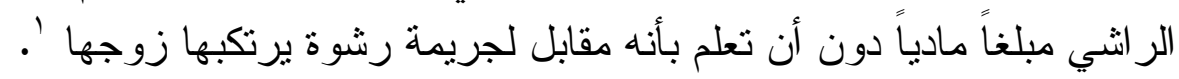

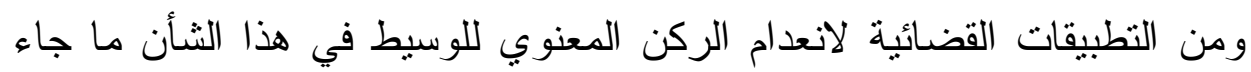
به فرع هيئة الرقابة و التحقيق بمنطقة جاز ان ، ومما جاء في حيثيات الحكم ( ل...

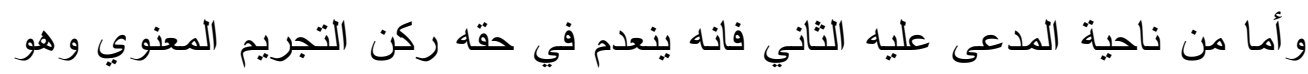

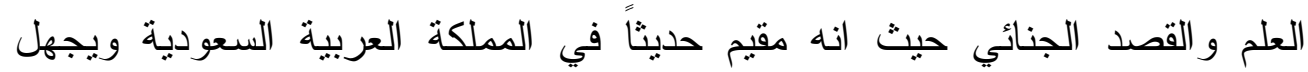

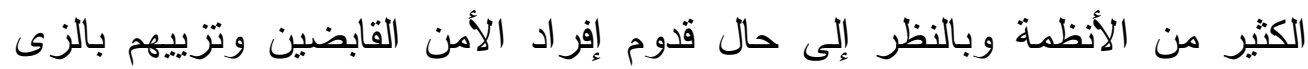

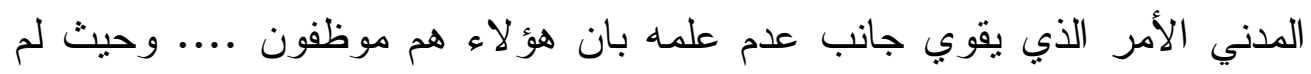

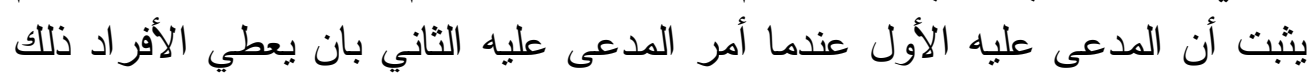

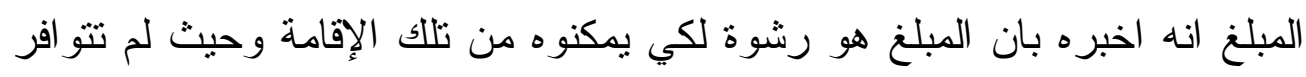

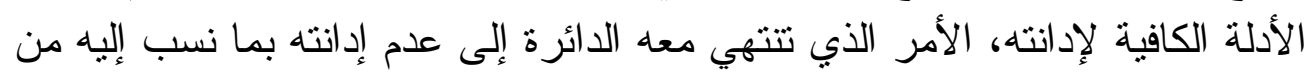

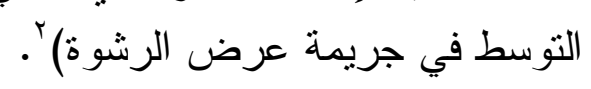

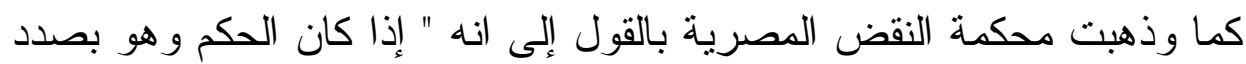

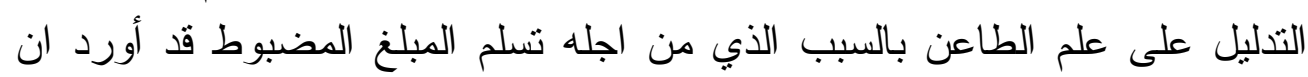
المحكمة ( وقد اطمأن الى وجدانها بصحة ما تم إسناده إلى المتهمين دونما تعويل

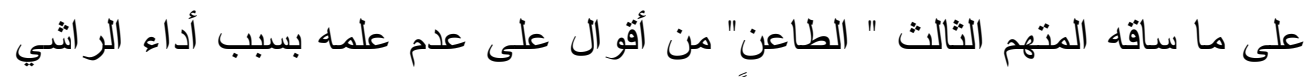

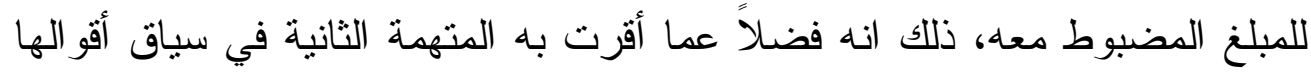

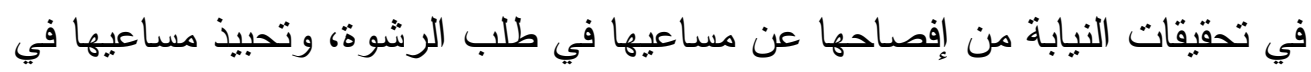
هذا الثأن ، فان في مسلكه و البادي بإعطاء رقم حسابه للمتهم الأول و الذي تخليه

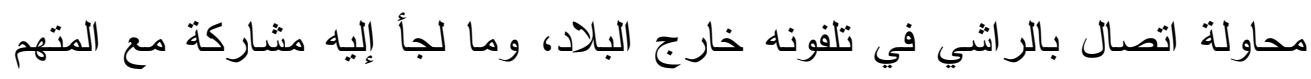
الأول من محاو لات سنر نشاطهما في طلب الرشوة التي تحدد المتهم الثالث

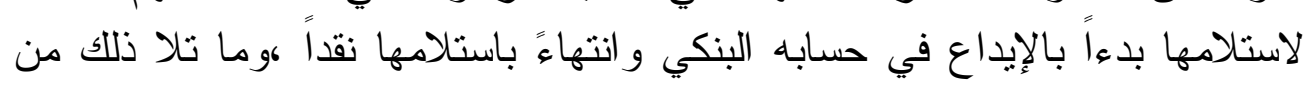

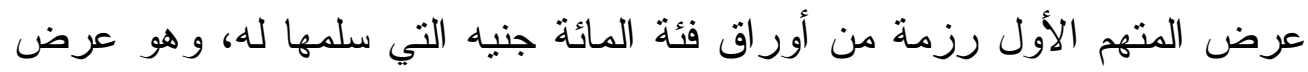

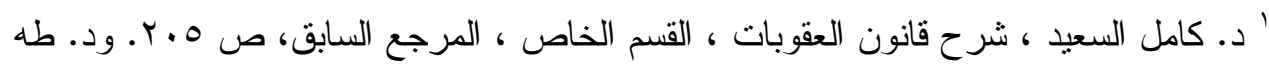

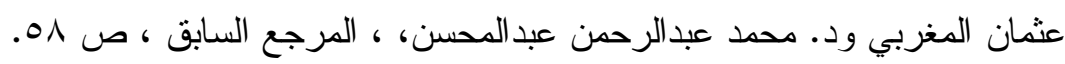

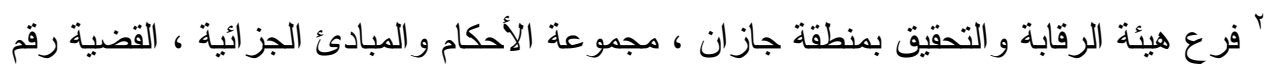

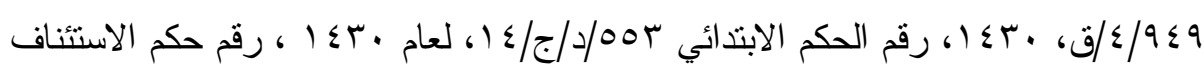

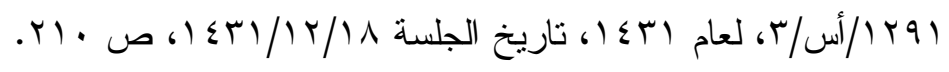


يرد محمو لا على ما تقدم من شو اهد، كاشفاً بغير لبس عن دوره في استلام الرشوة

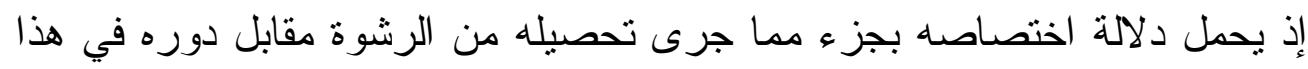

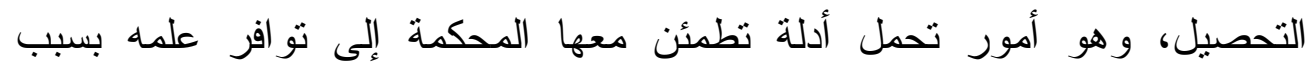
تحصيل المبالغ، و انه نتاج تحصيل رشوة مما انصرف إليه خطاب الثار ع في المادة

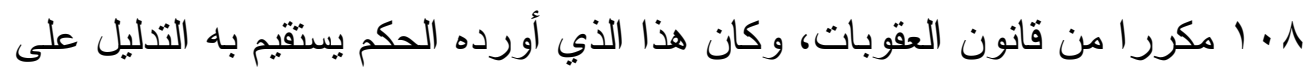
ثثوت القصد الجنائي في حق الطاعن، ونو افر علمه بالسبب الذي من أجله تسلم

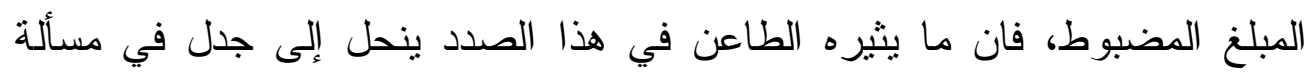
و اقعية تختص محكمة الموضوع بالفصل فيها، بغير معقب ما دامت تقيمها على ما في

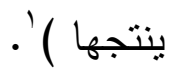
رابعاً:- العقوبات الجنائية استتاداً لنص الماد الهوبات 11 من نظام مكافحة جريمة الرشوة السعودي وفقاً لآخر

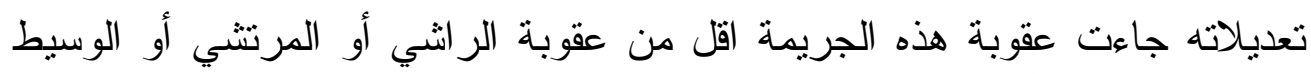

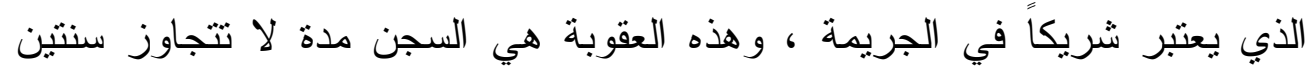

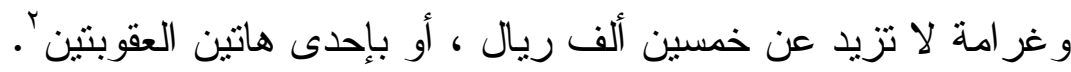

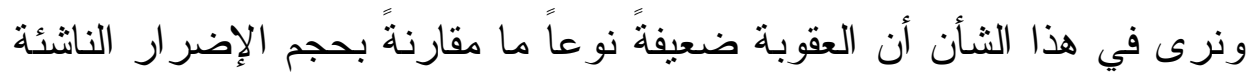

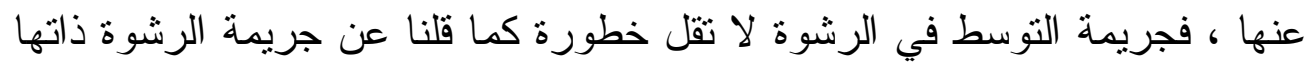

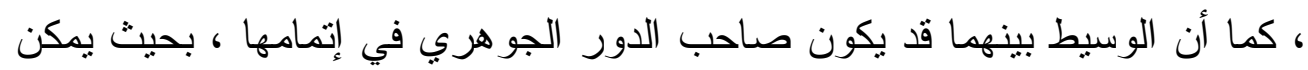

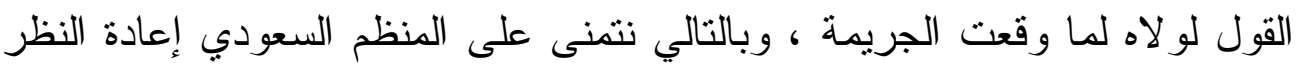

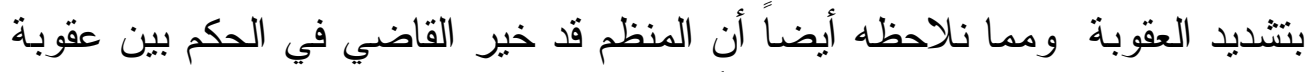

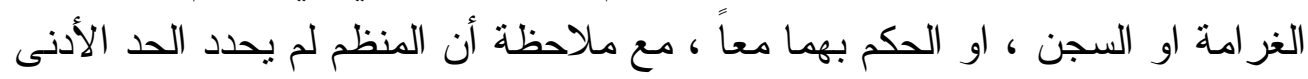
لعقوبتي الغر امة و السجن ، وبالتالي يجب الرجو الروع إلى التى القواعد العامة و التي تقرر

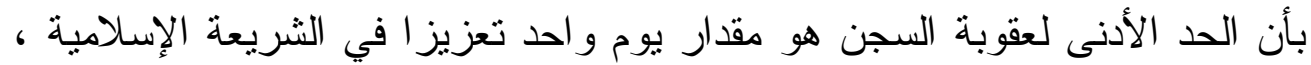

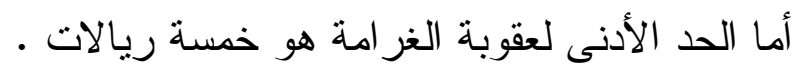

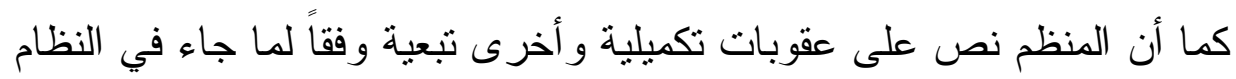

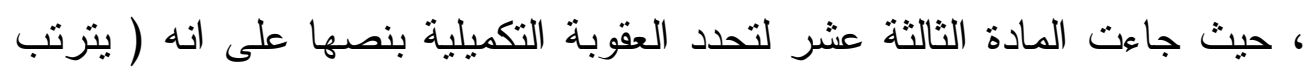

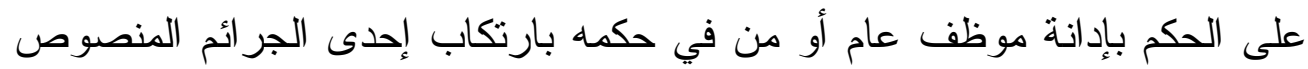

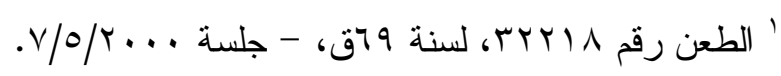

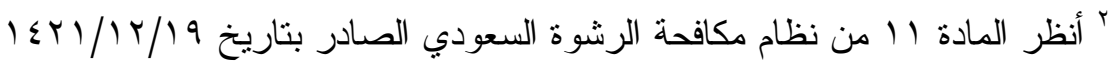


عليها في هذا النظام العزل من الوظيفة العامة وحرمانه من تولى الوظائف العامة أو

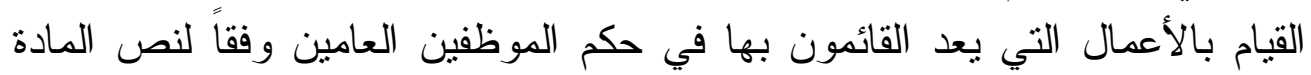
الثامنة من هذا النظام ()' '.

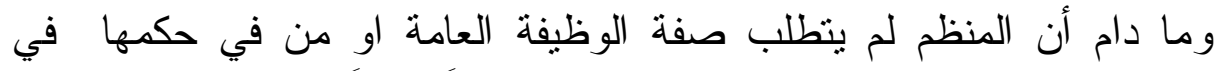

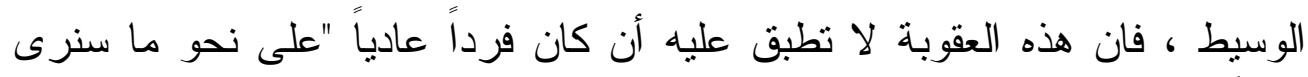

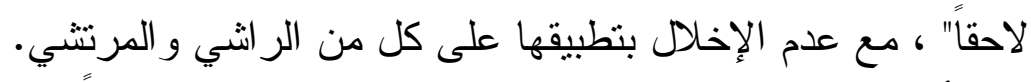

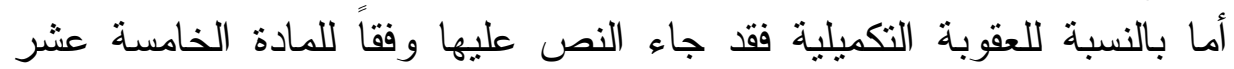
حيث نصت على انه ( بحكم في جميع الأحو ال بمصادرة المال أو الميزة أو الفائدة

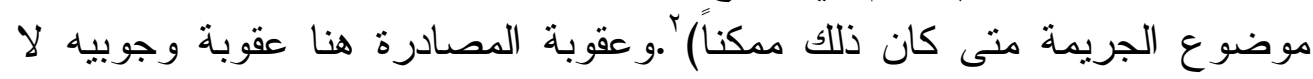

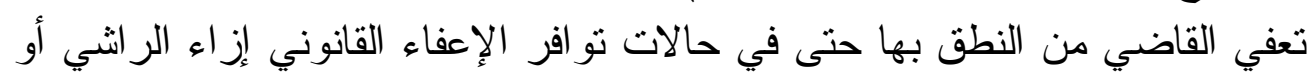

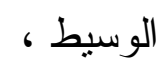

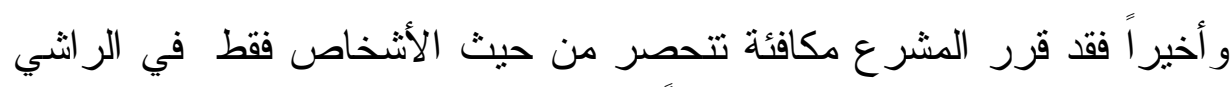

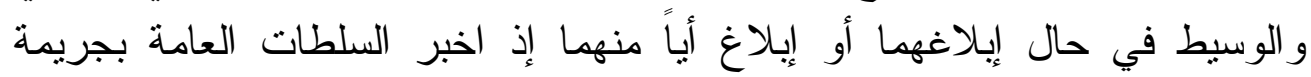

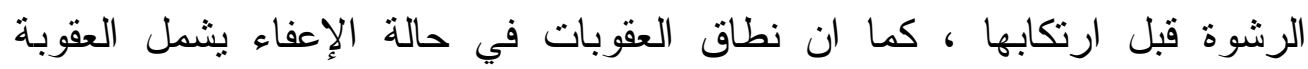

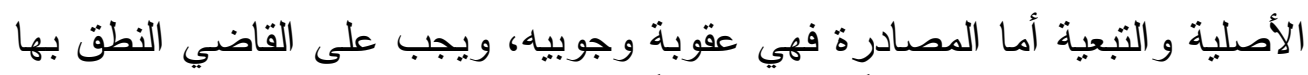

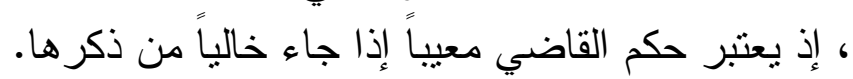

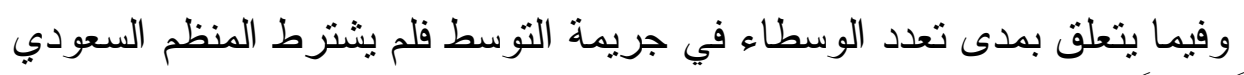

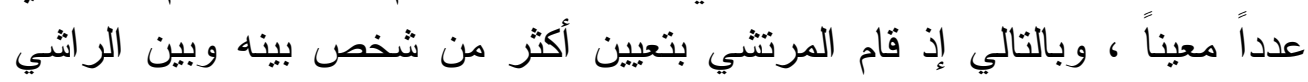

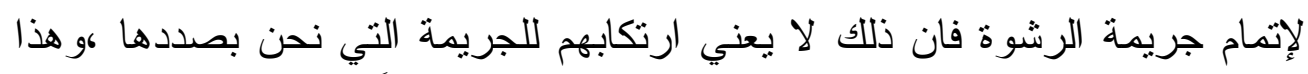

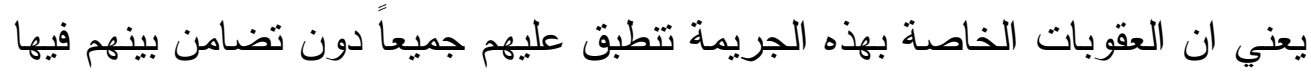

' المادة rا من نظام مكافحة الرشوة السعودي ، سبق الإثارة إليها.

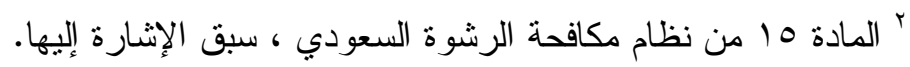




\section{المبمث الثاني \\ فرضيات الدراسة بشأن جريمة التوسط في اخذ العطية}

ثمة حالات لم يتعرض لها المنظم السعودي في نظام مكافحة الرشوة تتعلق

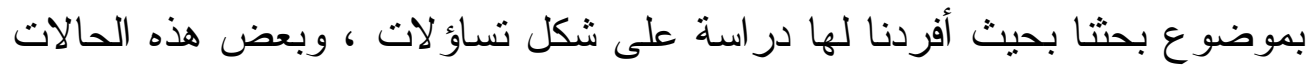

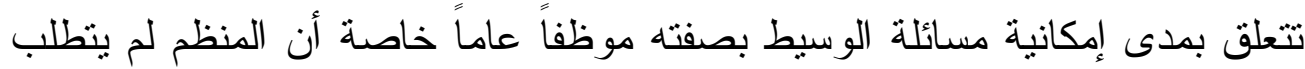
صفة معين بشأنه بدلالة نص المادة الحادي عشر الخاصة بهذه الجريمة ، كما أننا

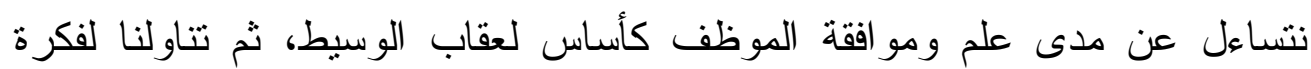

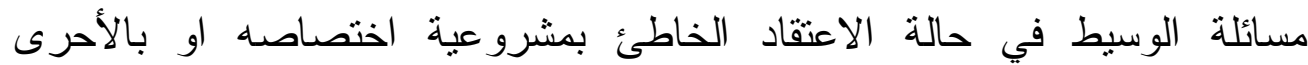

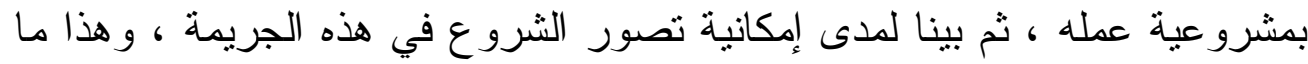
سنتولى بيانه تباعاً:

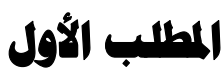

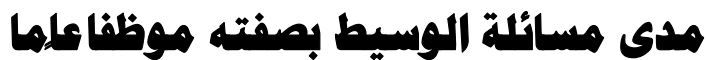

لنا أن نتساءل في هذا الثأن هل ثمة اختلاف في العقوبات فيما إذا كان الوسيط

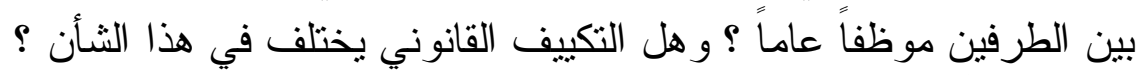

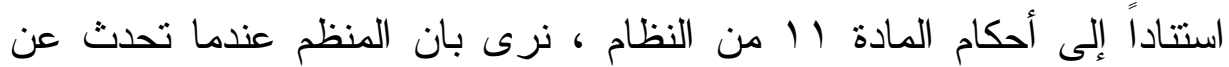

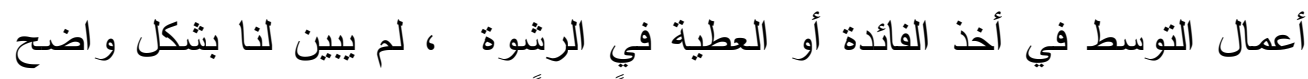

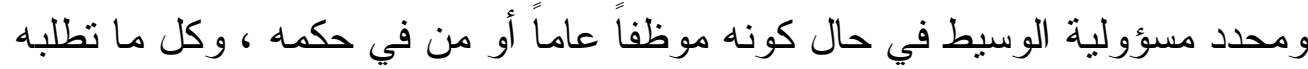

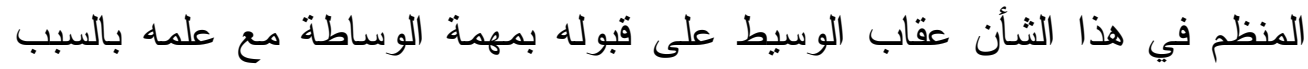

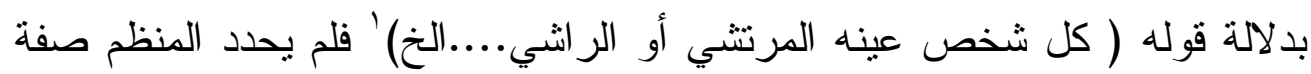

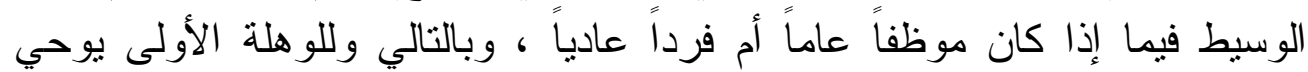

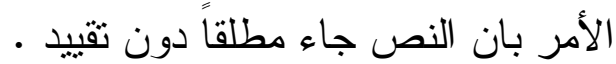
ولكن بالرجوع إلى أحكام المادة العاثرة من هذا هون النظام نجد تطبيقاً لها و الحالة

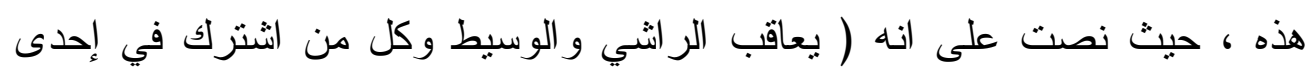
الجرائم الواردة في هذا النظام بالعقوبة المنصوص عليها في المادة التي تجرمها

' راجع الماد 11 1 من نظام مكافحة الرشوة السعودي ، سبق الإشارة إليها. 
كويعتبر شريكا في الجريمة كل من اتفق أو حرض أو ساعد في ارتكابها مع علمه

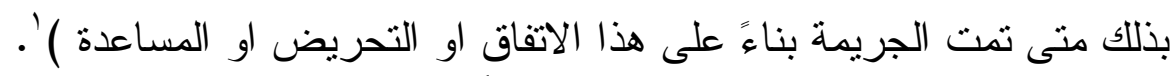

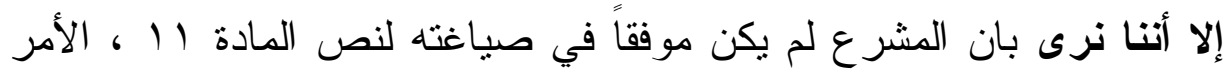

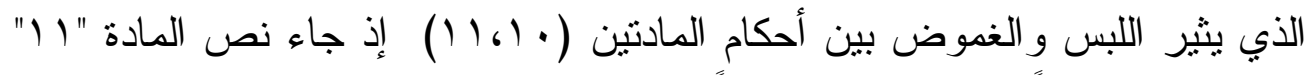

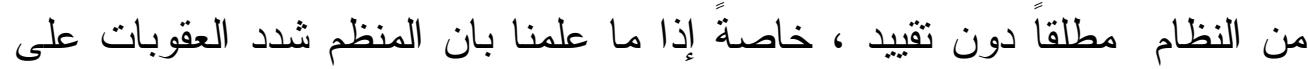

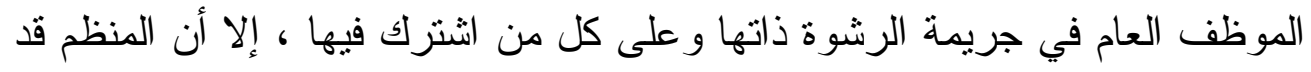

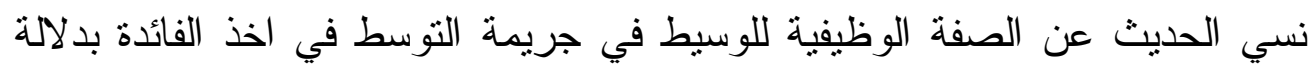

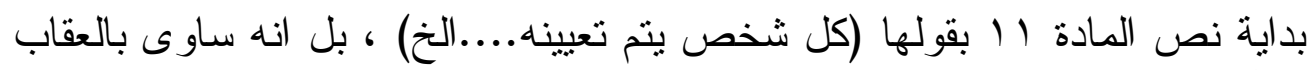

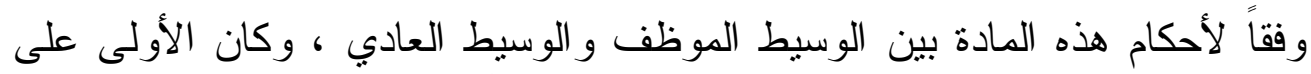

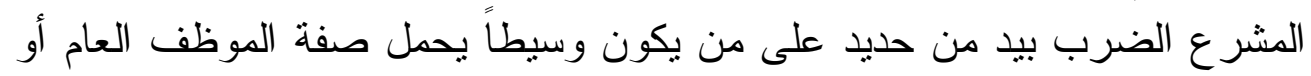

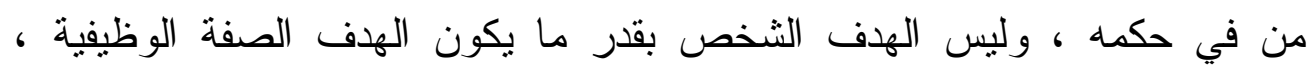

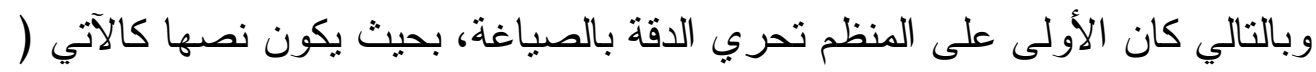

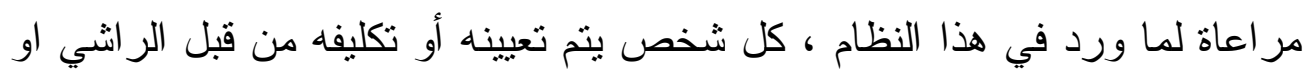

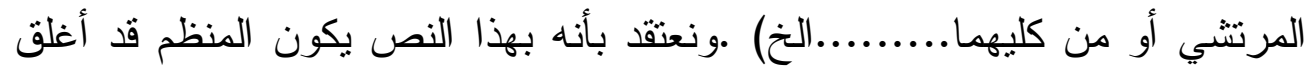
الباب إز اء أي تساؤل يُّنار بهذا الخصوص.

\section{الإطبا الثانبي}

\section{مدى علم وموافقة المهظف كأساس لهقاب الوسيط}

ثمة اتجاه في الفقهَ يذهب بالقول إلى أن معاقبة الوسيط يتطلب بحكم الضرورة

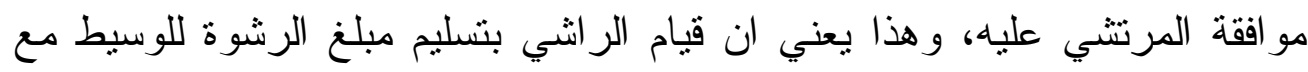

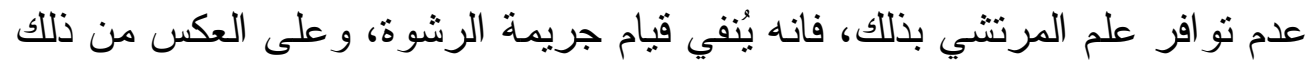

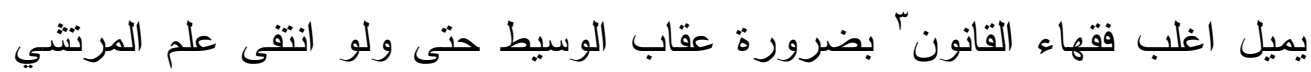

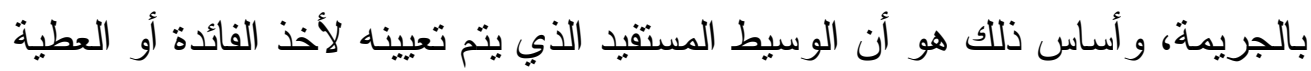

' المادة • ل أمن نظام مكافحة الرشوة السعودي ، سبق الإثارة إليها.

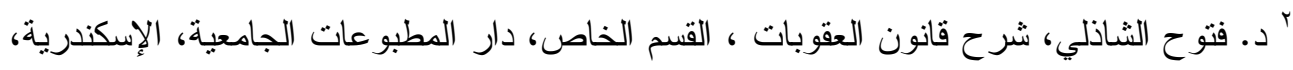
. $10 \mathrm{~V}$.

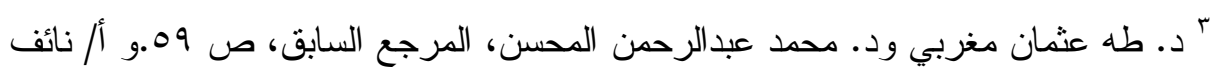

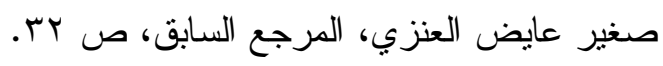


سواء من قبل المرتثي او الرانشي يوافق عليه المرتنثي بعد علمه به ، فالوسيط

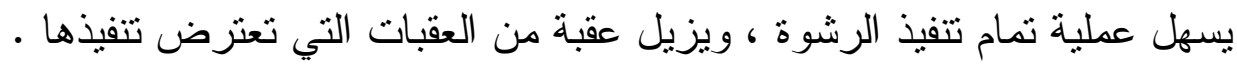

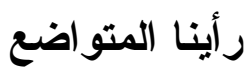

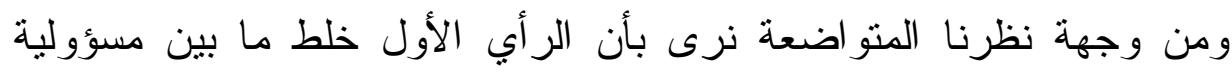

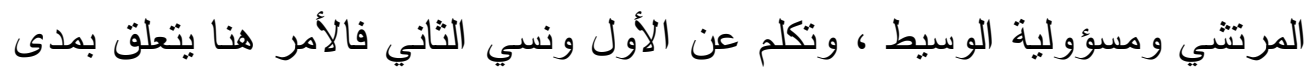

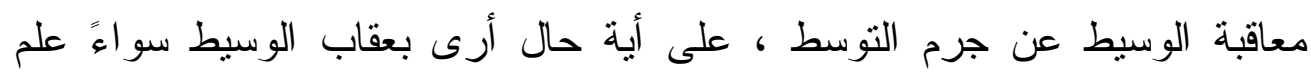

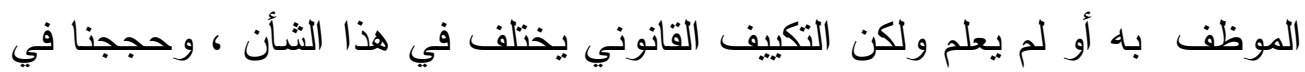

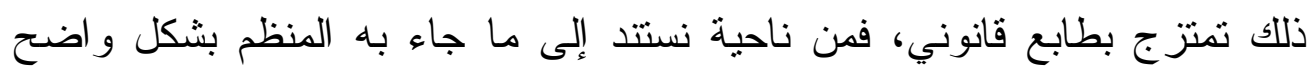

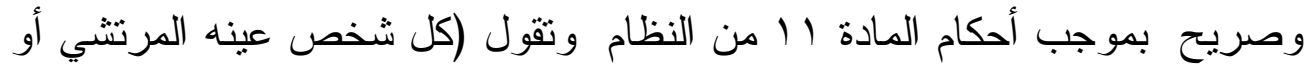

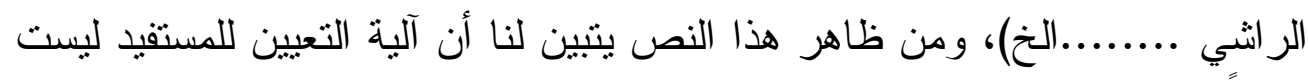

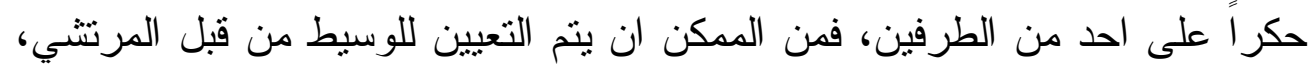

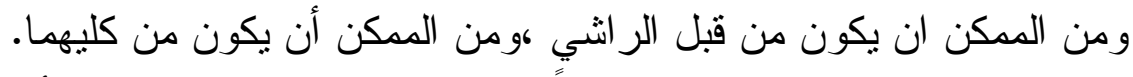

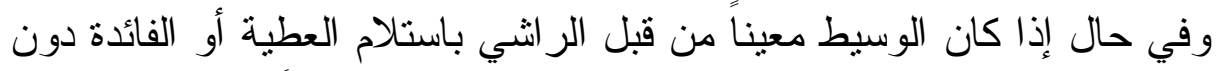

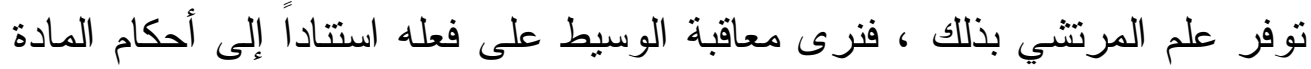

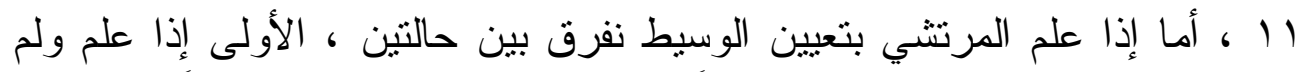

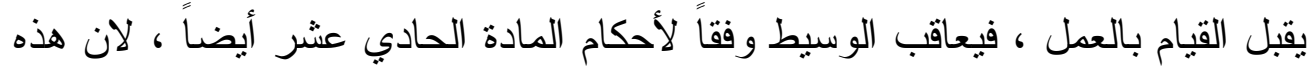

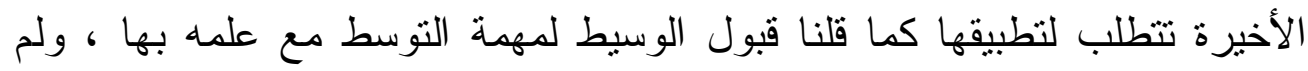
تتطلب مو افقة او عدم مو اققة المرتثي ، و هذا كاف في حد ذاته لقيام الجريمة بحقه لونه

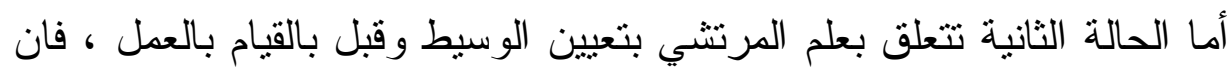

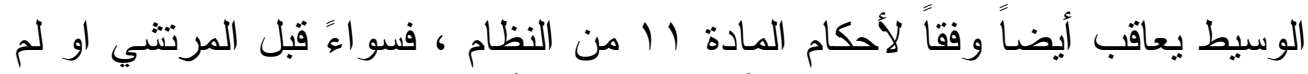

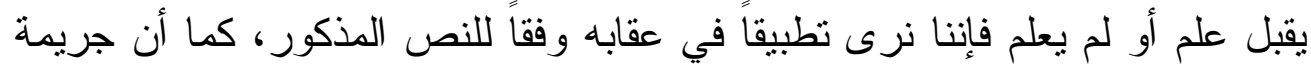

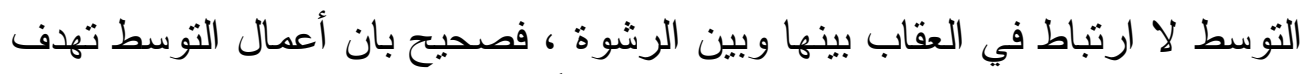

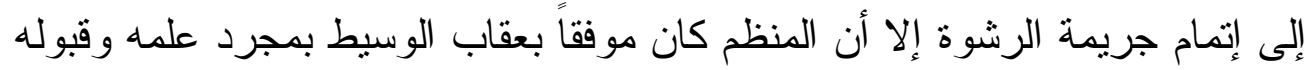
لمهمة التوسط بين الطرفين.

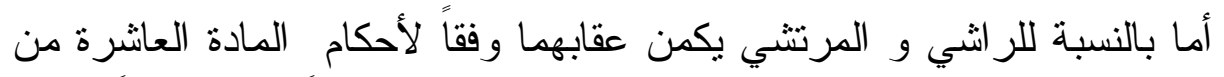
هذا النظام' ، أضف إلى ذلك إلى اعتبار سلوك الوسيط سلوكاً غير شريفاً لأخذه

' راجع المادة · ل من نظام مكافحة جريمة الرشوة السعودي. 
العطية أو الفائدة أو قبوله لها ، مع تو افر علمه بأنها مقابل للرشوة، فهو سلوك شائن لا يمنع من عقابه قانوناً بصرف النظر عن تو افر علم المرتشي من عدماه، و لا يخلو

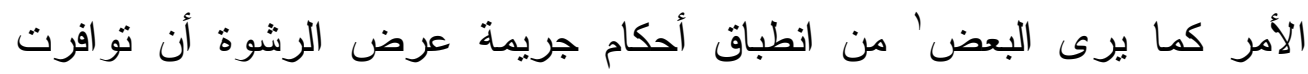
أركانها.

و لا يفوتتا في هذا السياق من تسجيل ملاحظة على المنظم السعودي بما جاء

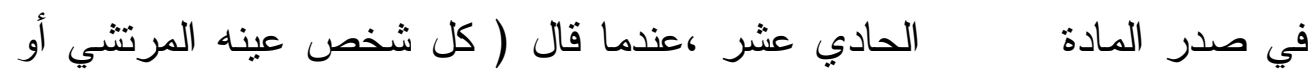

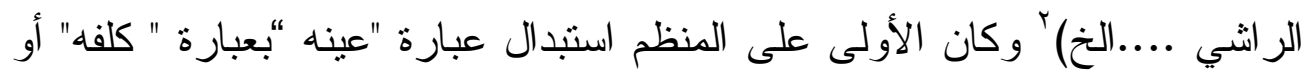

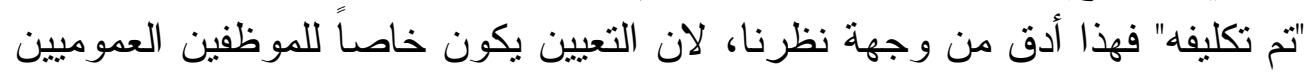

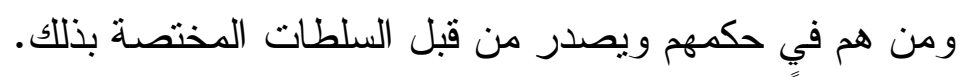
وترتيباً على ما سبق فان التوسط في الرشوة يكون بناء على تكليف أو تعيين إما

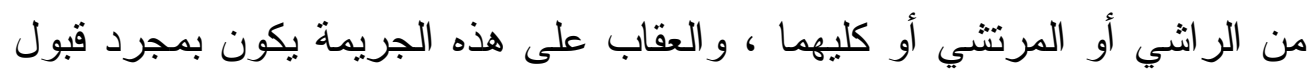

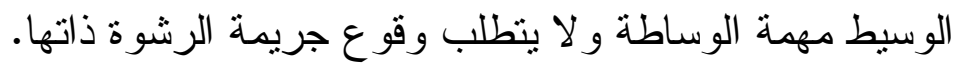

\section{الإلب الثالث}

\section{هدى عقاب الوسيط على العلم اللاهق لقبوله مهمة الوساطة}

تفترض هذه الحالة قبول الوسيط لمهمة الوساطة بناءً على تكليف من قبل

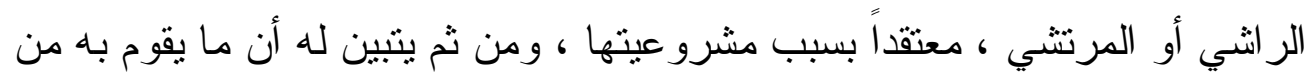

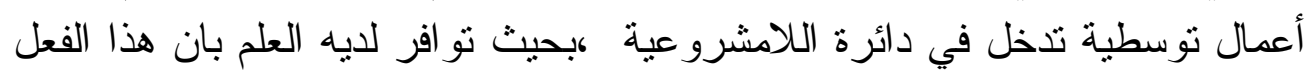

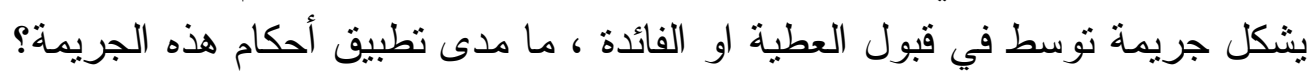

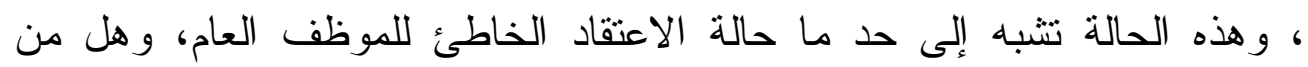

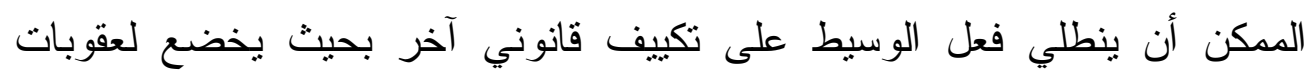

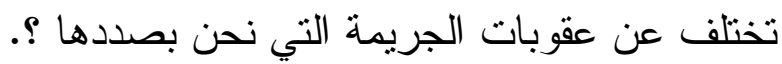

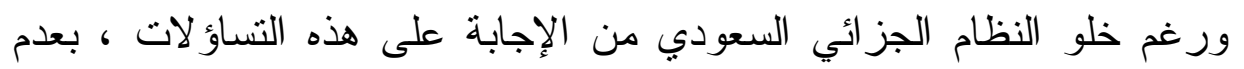

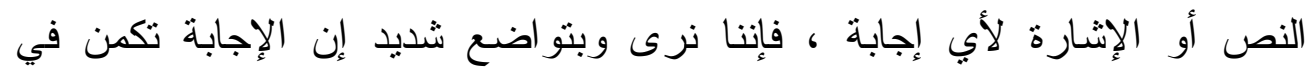

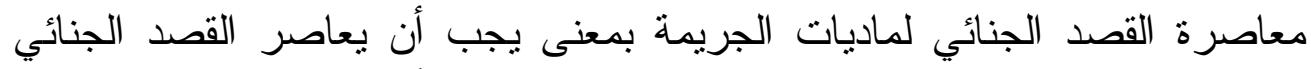

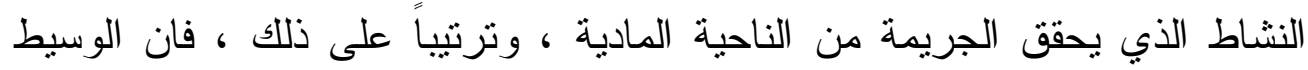

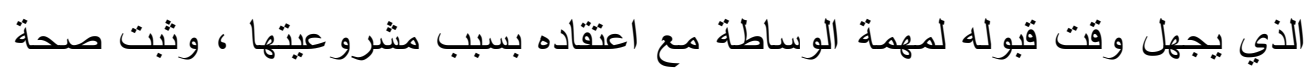

' أ / نائف صغير عايض العنزي، المرجع السابق ، ص r بـ.

' راجع المادة 11 من نظام مكافحة الرشوة السعودي ، سبق الإنشارة إليها. 


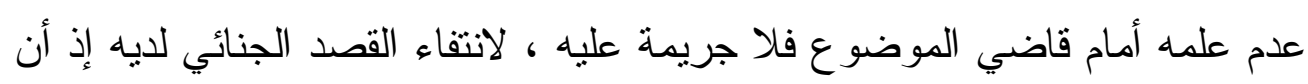

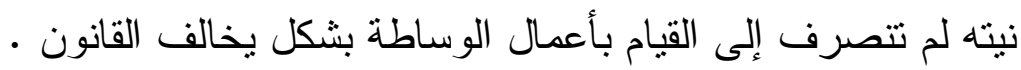

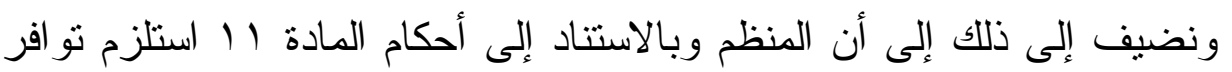

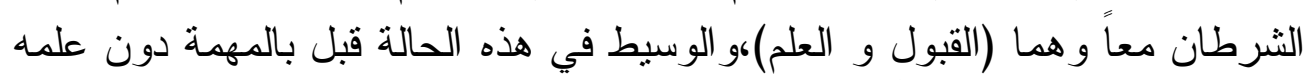

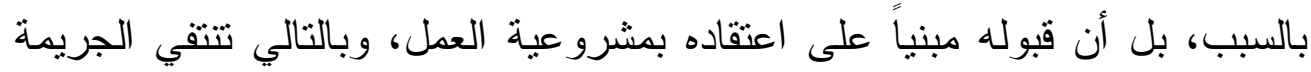

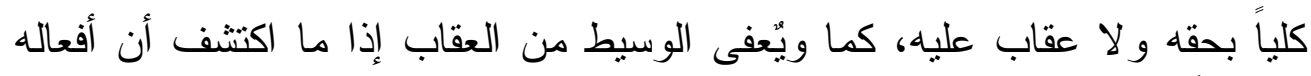

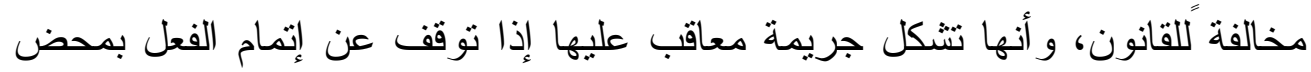

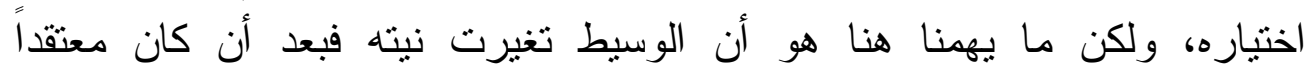

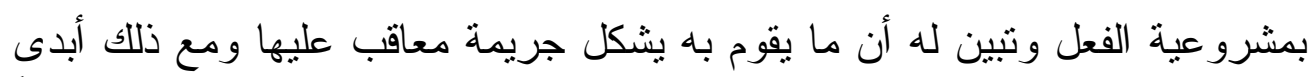
تزحيبا لها وبالمضي بها ، فلا مناص من تطبيق أحكام جريمة التوسط عليه وفئ وفئاً

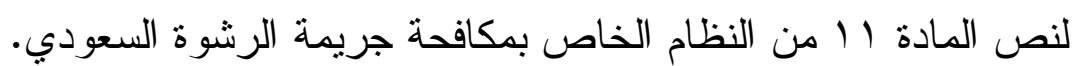

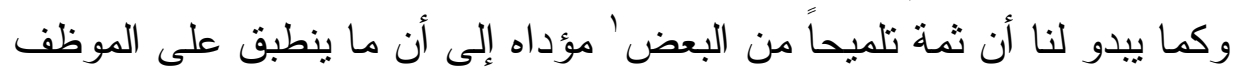

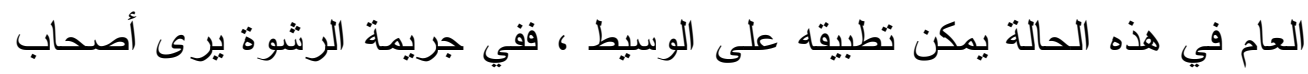

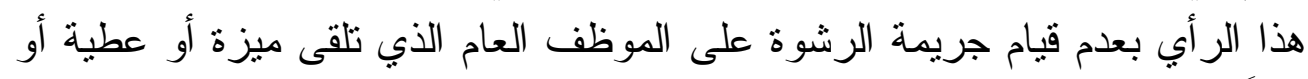

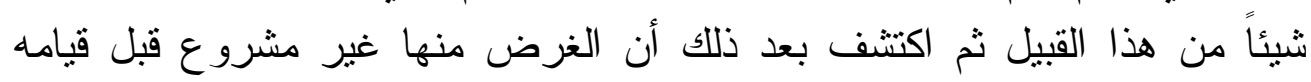

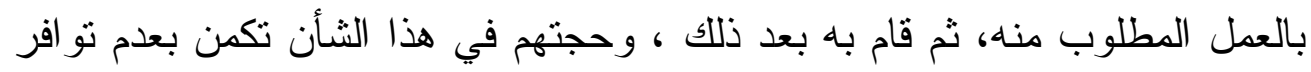
القصد الجنائي لدى الموظف قبل تمام الركن المادي للجريمة.

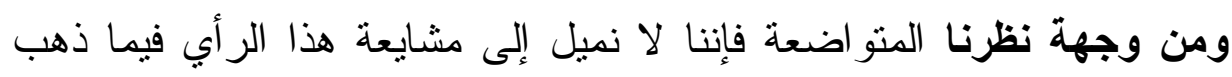

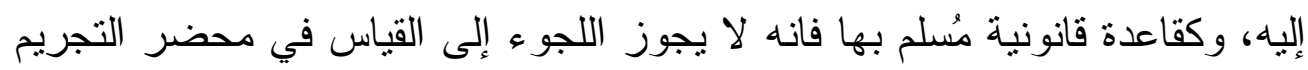

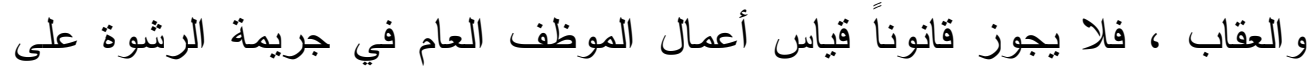

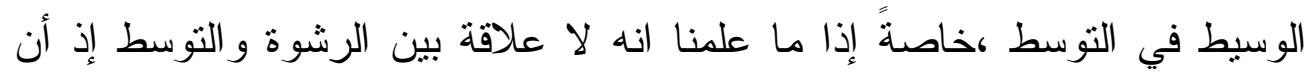

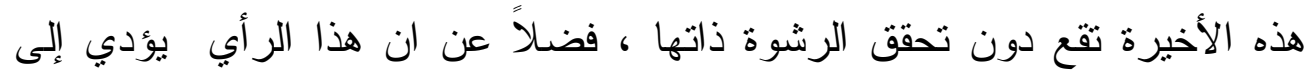

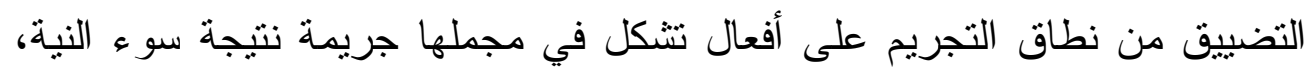
فضلاً عن أن هذا القول يتتافى مع أهداف ومقتضيات السياسة الجنائية و التي تهدف إلى الإحاطة بكافة صور هذه الجريمة.

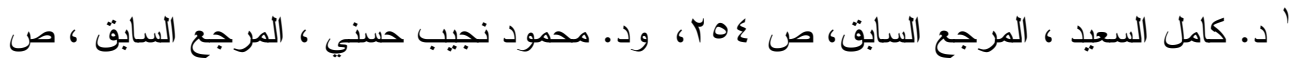

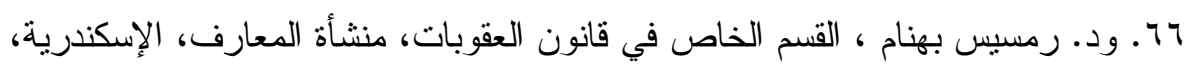
$.0 Y$. $197 \varepsilon$ 


\section{الإطب الرابع}

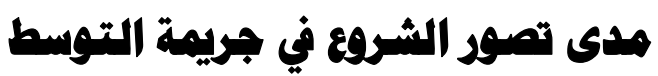

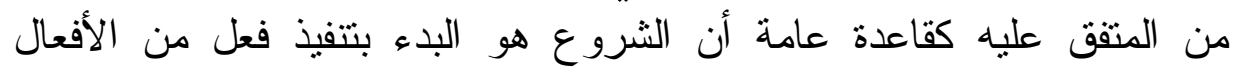

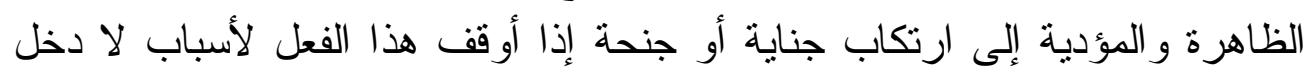

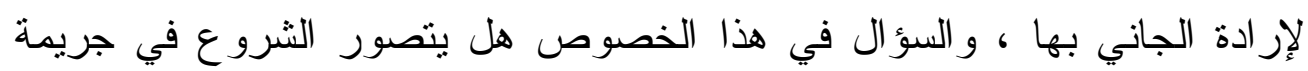
التوسط في قبول العطية أو الفائدة من جانب الوسيط الوسيط إذا ما حال بينه وبين إتمام

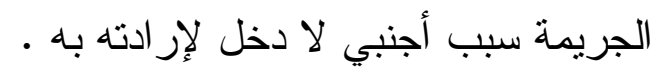

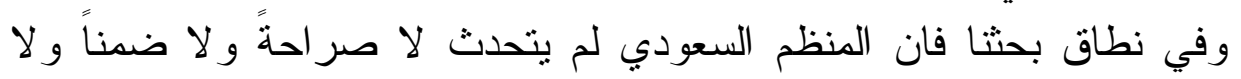

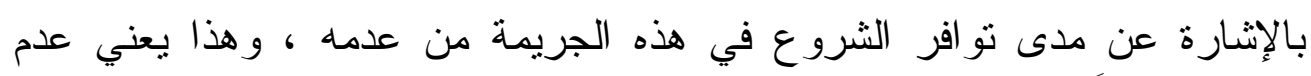

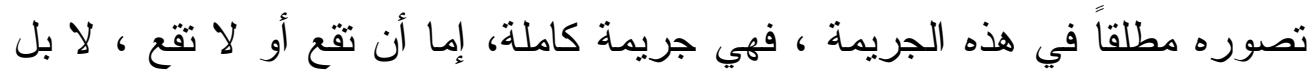

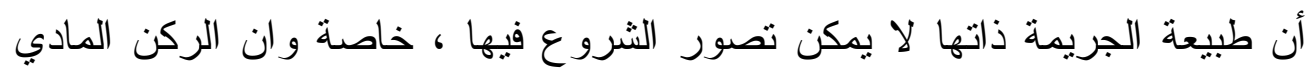

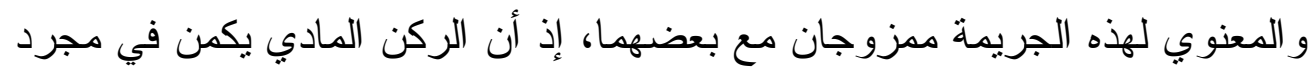

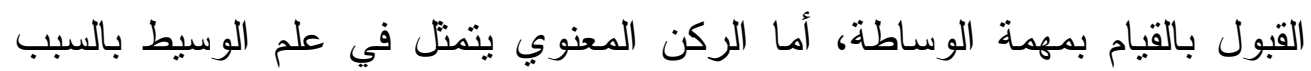

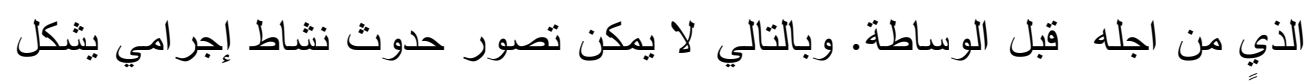
بدءاً في التنفيذ في هذه الجريمة. 


\section{النتائج والتوصيات}

تقوم الدراسة على إدراج النتائج التي توصلت لها ممزوجةً بأهم التوصيات و التي من الممكن ان تكون لها فائدة قانونية وذللك على النحو الآتي:-

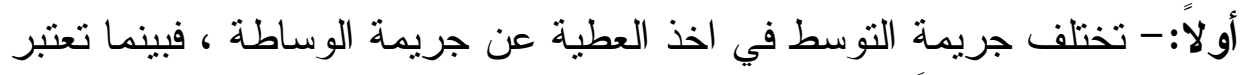

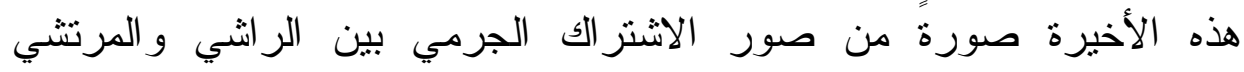

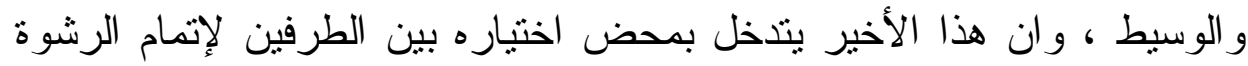

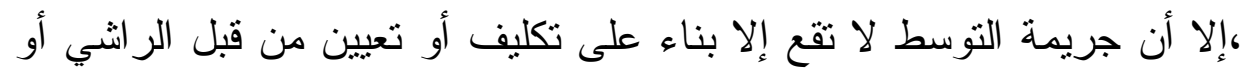
المرنتي أو كليهما.

ثانياً:- تعتبر جريمة التوسط إحدى صور الجرائم الملحقة بجريمة الرشوة ، ورغم فداحة خطرها وما يترتب عليها من إضرار فان المنظم عاقب عليها

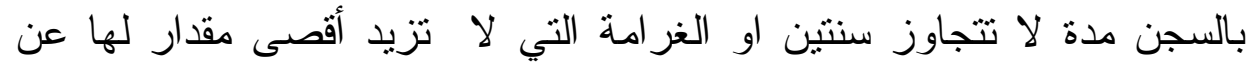

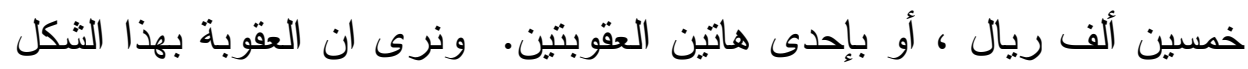

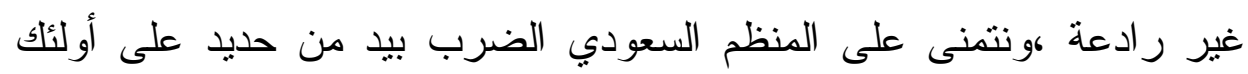
المتنخلين بإتمام جريمة الرشوة لما يلعبونه من دور هام هام وحيوي في تحقيقها وذلك بتتديد العقاب عليهم .

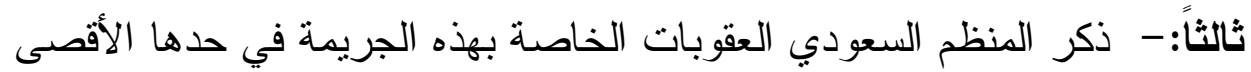

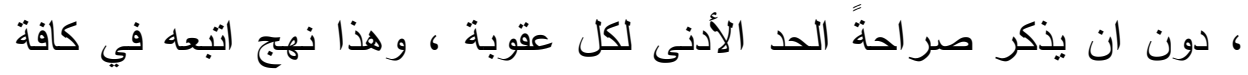

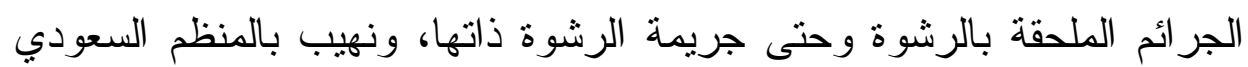

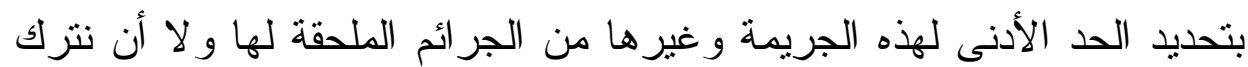

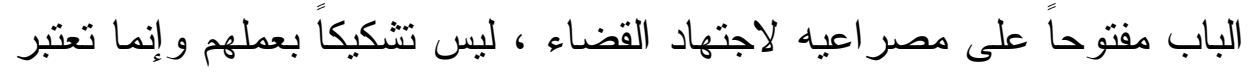

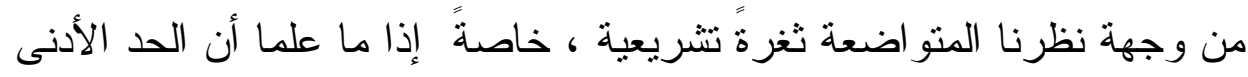

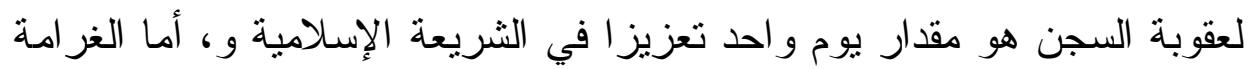

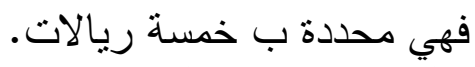

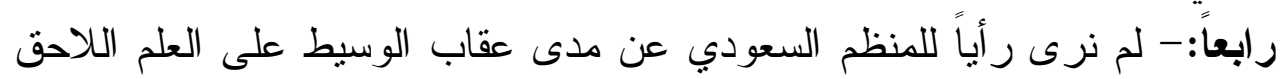

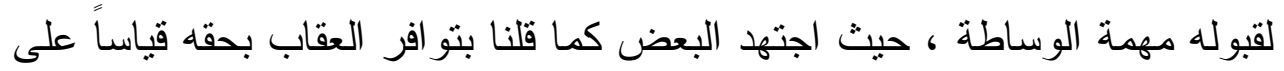

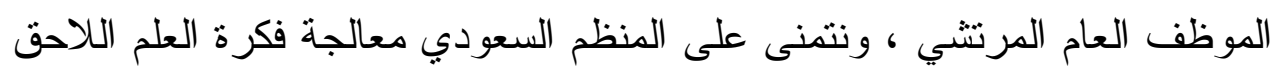

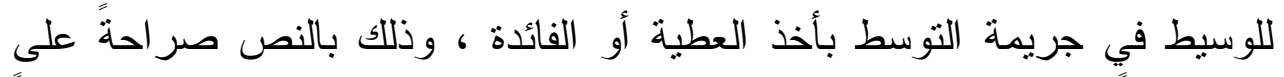

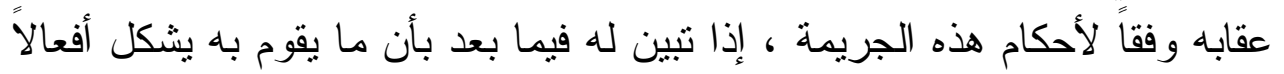

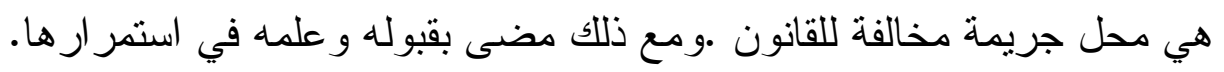


خامساً:- لا يمكن تصور الثروع في جريمة التوسط بأخذ العطية او الفائدة ، وهذا

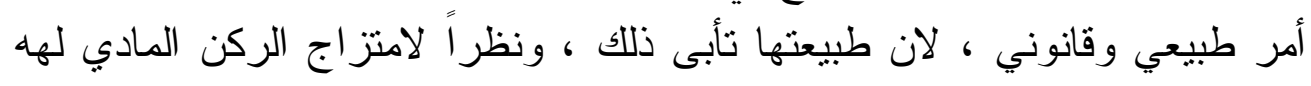

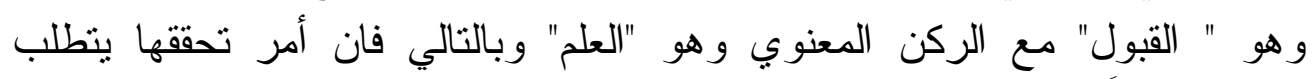
تو افر هما معاً.

سادساً:- جاءت صياغة نص المادة " الا" بشكل يثير اللبس و الغموض بينها وبين

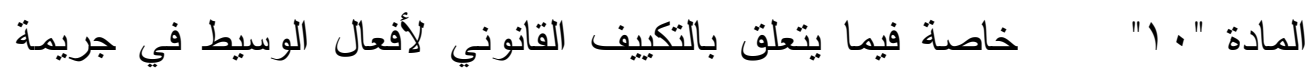

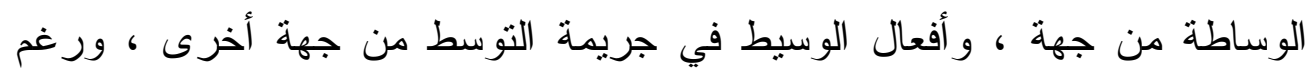

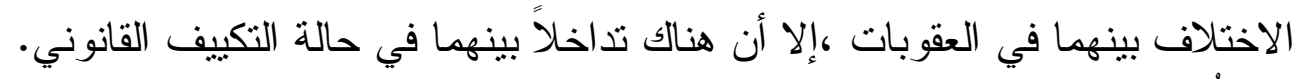

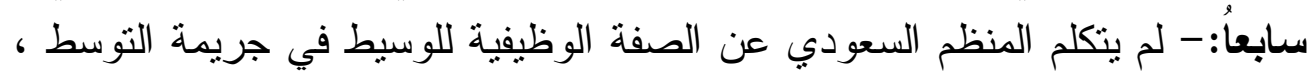
إذ انه لم يتطلب ذلك بدلالة نص المادة 11 ، ، بحيث ساوى في العقاب بين الوسيط

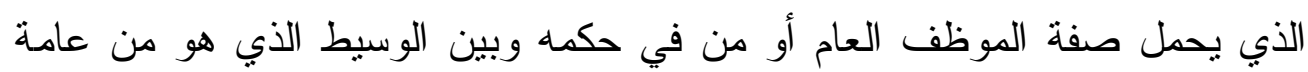
الناس، ونرى في هذا الثأن أن المنظم ما دام انه تشدد بالعقاب على الثى الموظف ولف العام

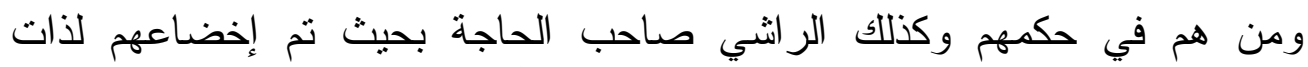

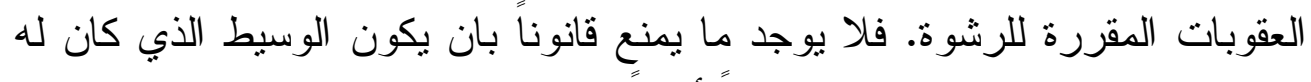

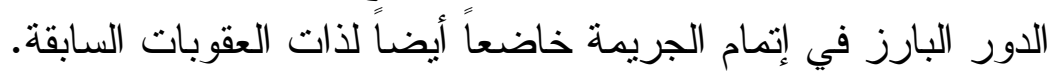

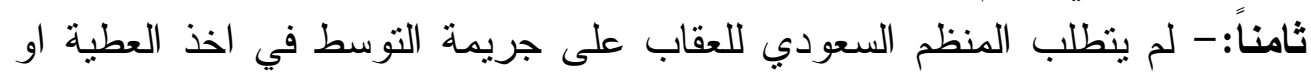

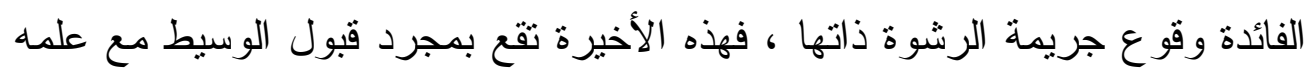

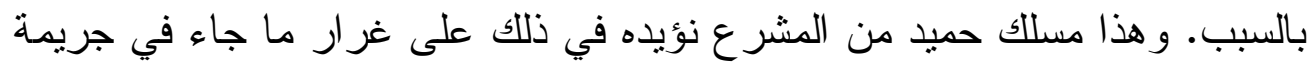

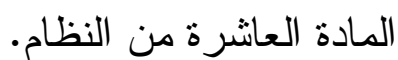
تاسعاً:- لم يتطلب المنظم السعودي شكلاً معيناً في القبول الصادر من الصناء الوسيط للقيام

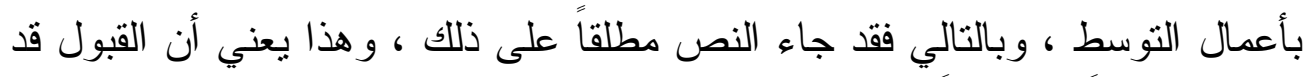

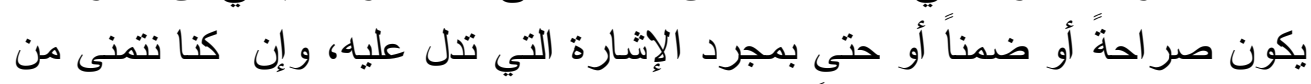

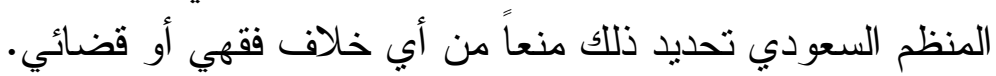
الباحث 